\title{
A 4-D climatology (1979-2009) of the monthly tropospheric aerosol optical depth distribution over the Mediterranean region from a comparative evaluation and blending of remote sensing and model products
}

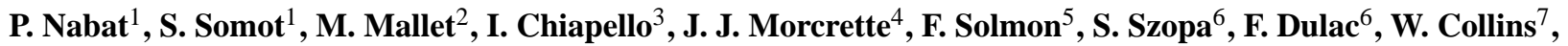 \\ S. Ghan ${ }^{8}$, L. W. Horowitz ${ }^{9}$, J. F. Lamarque ${ }^{10}$, Y. H. Lee ${ }^{11}$, V. Naik ${ }^{12}$, T. Nagashima ${ }^{13}$, D. Shindell ${ }^{11}$, and R. Skeie ${ }^{14}$ \\ ${ }^{1}$ Météo-France, UMR3589, CNRS - CNRM-GAME, Centre National de Recherches Météorologiques, 42 avenue G. Coriolis, \\ 31057 Toulouse cedex 1, France \\ ${ }^{2}$ Laboratoire d'Aérologie, UMR 5560, 16 avenue Édouard Belin, 31400 Toulouse, France \\ ${ }^{3}$ Laboratoire d'Optique Atmospérique, CNRS/Université Lille 1, UMR 8518, 59655 Villeneuve d'Ascq, France \\ ${ }^{4}$ European Centre for Medium-Range Weather Forecasts, Reading, UK \\ ${ }^{5}$ The Abdus Salam International Center for Theroretical Physics, Strada Costiera 11, 34100 Trieste, Italy \\ ${ }^{6}$ Laboratoire des Sciences du Climat et de l'Environnement, LSCE-IPSL, CEA-CNRS-UVSQ, 91191 Gif-sur-Yvette, France \\ ${ }^{7}$ Department of Meteorology, University of Reading, UK \\ ${ }^{8}$ Pacific Northwest National Laboratory, Richland, WA, USA \\ ${ }^{9}$ NOAA Geophysical Fluid Dynamics Laboratory, Princeton, NJ, USA \\ ${ }^{10}$ NCAR Earth System Laboratory, National Center for Atmospheric Research, Boulder, CO, USA \\ ${ }^{11}$ NASA Goddard Institute for Space Studies and Columbia Earth Institute, New York, NY, USA \\ ${ }^{12}$ UCAR/NOAA Geophysical Fluid Dynamics Laboratory, Princeton, NJ, USA \\ ${ }^{13}$ National Institute for Environmental Studies, Tsukuba, Japan \\ ${ }^{14}$ Center for International Climate and Environmental Research-Oslo (CICERO), Oslo, Norway
}

Correspondence to: P. Nabat (pierre.nabat@meteo.fr)

Received: 18 October 2012 - Published in Atmos. Meas. Tech. Discuss.: 28 November 2012

Revised: 2 April 2013 - Accepted: 13 April 2013 - Published: 17 May 2013

\begin{abstract}
Since the 1980s several spaceborne sensors have been used to retrieve the aerosol optical depth (AOD) over the Mediterranean region. In parallel, AOD climatologies coming from different numerical model simulations are now also available, permitting to distinguish the contribution of several aerosol types to the total AOD. In this work, we perform a comparative analysis of this unique multiyear database in terms of total AOD and of its apportionment by the five main aerosol types (soil dust, seasalt, sulfate, black and organic carbon). We use 9 different satellite-derived monthly AOD products: NOAA/AVHRR, SeaWiFS (2 products), TERRA/MISR, TERRA/MODIS, AQUA/MODIS, ENVISAT/MERIS, PARASOL/POLDER and MSG/SEVIRI, as well as 3 more historical datasets: NIMBUS7/CZCS, TOMS (onboard NIMBUS7 and Earth-
\end{abstract}

Probe) and METEOSAT/MVIRI. Monthly model datasets include the aerosol climatology from Tegen et al. (1997), the climate-chemistry models LMDz-OR-INCA and RegCM-4, the multi-model mean coming from the ACCMIP exercise, and the reanalyses GEMS and MACC. Ground-based Level2 AERONET AOD observations from 47 stations around the basin are used here to evaluate the model and satellite data. The sensor MODIS (on AQUA and TERRA) has the best average AOD scores over this region, showing a relevant spatiotemporal variability and highlighting high dust loads over Northern Africa and the sea (spring and summer), and sulfate aerosols over continental Europe (summer). The comparison also shows limitations of certain datasets (especially MERIS and SeaWiFS standard products). Models reproduce the main patterns of the AOD variability over the basin. The MACC

Published by Copernicus Publications on behalf of the European Geosciences Union. 
reanalysis is the closest to AERONET data, but appears to underestimate dust over Northern Africa, where RegCM-4 is found closer to MODIS thanks to its interactive scheme for dust emissions. The vertical dimension is also investigated using the CALIOP instrument. This study confirms differences of vertical distribution between dust aerosols showing a large vertical spread, and other continental and marine aerosols which are confined in the boundary layer. From this compilation, we propose a 4-D blended product from model and satellite data, consisting in monthly time series of 3-D aerosol distribution at a $50 \mathrm{~km}$ horizontal resolution over the Euro-Mediterranean marine and continental region for the 2003-2009 period. The product is based on the total AOD from AQUA/MODIS, apportioned into sulfates, black and organic carbon from the MACC reanalysis, and into dust and sea-salt aerosols from RegCM-4 simulations, which are distributed vertically based on CALIOP climatology. We extend the 2003-2009 reconstruction to the past up to 1979 using the 2003-2009 average and applying the decreasing trend in sulfate aerosols from LMDz-OR-INCA, whose AOD trends over Europe and the Mediterranean are median among the ACCMIP models. Finally optical properties of the different aerosol types in this region are proposed from Mie calculations so that this reconstruction can be included in regional climate models for aerosol radiative forcing and aerosolclimate studies.

\section{Introduction}

The Mediterranean region has been identified as a crossroads of air masses carrying numerous and various aerosol types (Lelieveld et al., 2002), and the relatively high aerosol load encountered over the region can potentially lead to strong effects on the regional radiative budget, climate and ecosystems of the Mediterranean (Rodá et al., 1993; Rosenfeld et al., 2001; Bergamo et al., 2008; Guieu et al., 2010). Numerous anthropogenic and natural sources over this region lead to the presence of different aerosols, such as industrial and urban aerosols from Europe and North African towns, forest fires, biomass burning from Eastern Europe, dust aerosols from Africa and marine particles. This diversity results in a large variety in physico-chemical and optical aerosol properties over the basin (Basart et al., 2009), highly variable in space and time, driving their interactions with shortwave (SW) and longwave (LW) radiation, with ensuing impacts on climate. In order to identify and quantify these impacts with regional climate models, a robust 4-D aerosol content database over the region is required to be used as a reference for radiative calculations.

The atmospheric aerosol content can be represented by the Aerosol Optical Depth (AOD), which is the vertical integral over an atmospheric column of the fraction of incident light scattered and absorbed by aerosols. This optical parameter is often used as input for calculations of aerosol direct and semi-direct radiative forcing in Regional Climate Models (RCMs). Several AOD datasets exist over the Mediterranean region, both satellite-derived (e.g., MODIS, MISR, SEVIRI) and model-simulated products (e.g., MACC, RegCM-4) which will be discussed in Sect. 2. All these satellite-derived products are commonly evaluated against ground-based measurements, from the AERONET network notably (e.g., Vidot et al., 2008; Levy et al., 2010). Various authors have already used AOD derived by several satellite teams from satellite data over the Mediterranean, using for example MODIS (Barnaba and Gobbi, 2004; Papadimas et al., 2008, 2009; Nabat et al., 2012), the association of MODIS and TOMS (Hatzianastassiou et al., 2009) or the SeaWiFS sensor (Antoine and Nobileau, 2006), but few have compared different AOD satellite products between them. Bréon et al. (2011) have compared AOD from POLDER, MODIS, MERIS, SEVIRI and CALIOP at the global scale. This study has shown that the MODIS AOD product has the most reliable estimate of the total AOD over ocean and land. Carboni et al. (2012) have provided an intercomparison of Saharan dust aerosols retrieved by various satellite instruments (e.g., MODIS, MISR and MERIS) during a strong event in March 2006, showing significant differences between them. Over ocean, Myhre et al. (2005) have also underlined significant differences in AOD retrievals from 9 datasets between 1997 and 2000. The AeroCom exercise (http://nansen.ipsl.jussieu.fr/AEROCOM/) has enabled a comparison of aerosols from different global models: Kinne et al. (2006) have found a relative agreement in global mean AOD, evaluated between 0.11 and 0.14 in the different AeroCom models, against 0.135 for AERONET and 0.15 for satellite composites. Differences are larger at the regional scale. More recently, in the framework of the Atmospheric Chemistry and Climate Model Intercomparison Project (ACCMIP), Shindell et al. (2013a) have also underlined all global models were able to reproduce the main AOD patterns, but differ in individual aerosol components. Over Europe Zubler et al. (2011c) have compared several model climatologies showing the overestimation of AOD in the climatology of Tanré et al. (1984). All these comparative studies highlight the differences between the numerous AOD products, despite a generally reasonably good agreement with AERONET data. Over the Mediterranean region, an intercomparison between all these sensors and models has not been done to our knowledge.

This comparison could also help in the understanding of the impact of aerosols on the Mediterranean climate. The complexity of regional climate response to aerosols is reinforced in this region where local winds, complex coastlines and orography have strong interactions with the atmospheric flow. In this context, the use of high resolution modelling through RCMs is essential (Gibelin and Déqué, 2003; Gao et al., 2006; Giorgi and Lionello, 2008; Déqué and Somot, 2008; Herrmann et al., 2011). At present many RCMs use 
AOD monthly climatologies to take into account aerosol radiative forcing, for example ALADIN-Climate (Herrmann et al., 2011) and REMO (Jacob, 2001). Others do not have any aerosols (e.g., RegCM-3, Artale et al., 2010; PROMESRCM, Sanchez et al., 2004). Only few RCMs such as COSMO-ART (Zubler et al., 2011a) and RegCM-4 (Giorgi et al., 2012) have interactive schemes to generate natural and anthropogenic aerosols. These interactive modules are useful for studies at the daily scale and for future climate projections (e.g., Szopa et al., 2013). However, they might lead to biases when simulating present aerosol conditions, as the climatic biases impact the AOD field through emission, advection and wet deposition. Resorting to monthly climatologies can be justified for this reason, especially for hindcast simulations, targeting a realistic representation of the past decade. Given the strong aerosol impact on climate, the choice of the aerosol dataset is essential (Hohenegger and Vidale, 2005).

The objective of this work is to compare and evaluate the different existing multi-year datasets of aerosols in terms of monthly AOD at $550 \mathrm{~nm}$ over the Mediterranean basin, in order to set up a reference aerosol climatology. The comparison includes the following sensors: NOAA/AVHRR (1982-2007), SeaWiFS (1997-2010, 2 products), TERRA/MISR (2000-2010), TERRA/MODIS (20002010), AQUA/MODIS (2002-2010), ENVISAT/MERIS (2002-2010), PARASOL/POLDER (2005-2010) and MSG/SEVIRI (2005-2010). All these passive sensors, detailed in Sect. 2, which will be compared to each other and evaluated against ground-based observations from the AERONET network, provide monthly AOD fields, without any information on the vertical profiles of particles. We have also used the CALIPSO/CALIOP product to assess the vertical distribution of aerosols over five years (2006-2010). Finally, those remote-sensing datasets have been associated with model-simulated products, which provide AOD climatologies, as well as a vertical dimension for some of them. In addition, they offer the possibility of separating aerosols between different types. Five classes are generally distinguished in climate modelling: soil dust (SD), sea-salt (SS), black carbon (BC), organic carbon (OR) and sulfate (SU) aerosols. The following numerical model-based products will be assessed: the climatology from Tegen et al. (1997) (hereafter noted TEG97), the climate-chemistry models RegCM-4 (2000-2009) and LMDz-OR-INCA (1850-2100), the reanalyses GEMS (2003-2008) and MACC (20032010), and the multi-model mean coming from a subset of models taking part in the ACCMIP exercise. Before the 2000s, we also include in the present work retrievals from NIMBUS-7/CZCS (1978-1986), NIMBUS7/TOMS (1980-1992), METEOSAT/MVIRI (1984-1997) and EarthProbe/TOMS (1997-2000), as well as the models from the ACCMIP exercise. The intercomparison led in this study concerns the whole Mediterranean basin, both land and ocean surfaces. The domain of study is presented in Fig. 1, and includes the Mediterranean domain of the international WCRP/CORDEX initiative for high resolution regional climate modelling in the Mediterranean region (MedCORDEX: http://www.medcordex.eu). The Mediterranean basin and the Black Sea catchment basin are included in this domain. As a result of this comparison, a possible reconstruction of the aerosol field over the Mediterranean basin will be provided for use in RCMs, as well as an estimation of the different uncertainties. It should be noted that the present work focuses on tropospheric aerosols, and that consequently the consideration of volcanic aerosols will only be raised in the discussion part.

After a description of each aerosol dataset in Sect. 2, the comparison and evaluation of the different satellite-derived and model-simulated products is given in Sect. 3, considering both the spatial and temporal variability, and also the vertical distribution. The period before the 2000s when few satellite retrievals and models are available is studied separately. Section 4 presents our blended 4-D reconstruction of the aerosol field, as well as a discussion about optical properties notably before the concluding remarks in Sect. 5 .

\section{Dataset}

\subsection{Satellite data}

Aerosol information retrieved from different sets of satellite measurements is compared over the Mediterranean basin in the present work, in terms of aerosol optical depth at $550 \mathrm{~nm}$. Table 1 summarises their main characteristics (instrument, platform, period of study, spatial resolution and coverage). The following list includes the main aerosol sensors over the basin, and all of them will be evaluated against AERONET ground-based observations (when available) and compared with each other in this study. We have separated the ones retrieving data only before the 2000s, which cannot be evaluated against AERONET observations. Among these 11 datasets, only the ones covering the whole Mediterranean basin and surrounding land areas could be considered for a reconstruction purpose.

The MODerate resolution Imaging Spectroradiometer (MODIS) is a multi-spectral radiometer, designed to retrieve aerosol microphysical and optical properties over ocean and land (Tanré et al., 1997; Levy et al., 2007). It was launched both onboard TERRA (morning orbit) and AQUA (afternoon orbit) satellites. For this study, the official Level-3 monthly aerosol products (MOD08_M3 and MYD08_M3, collection 5.1) are used to get AOD. The traditional algorithm covers both ocean and land surfaces except deserts over a long period (since 2000 for TERRA and 2002 for AQUA) at a $1 \times 1^{\circ}$ resolution. Over the Sahara, the "Deep Blue" algorithm (Hsu et al., 2004) is needed to retrieve aerosols over this bright surface, instead of the land algorithm which is based on finding dark targets. The Deep Blue algorithm relies on the blue wavelengths and libraries of surface reflectance. Using data 
Table 1. Main characteristics of the different satellite sensors used in this study.

\begin{tabular}{lllrl}
\hline Instrument & Platform & Period of study & $\begin{array}{r}\text { Spatial } \\
\text { Resolution }\end{array}$ & Spatial coverage \\
\hline MODIS & AQUA & July 2002-December 2010 & $1^{\circ}$ & Ocean and land (including Sahara) \\
MODIS & TERRA & March 2000-December 2010 & $1^{\circ}$ & Ocean and land (including Sahara) \\
MISR & TERRA & March 2000-December 2010 & $0.5^{\circ}$ & Ocean and land (including Sahara) \\
POLDER & PARASOL & March 2005-December 2010 & $18.5 \mathrm{~km}$ & Ocean \\
SEVIRI & MSG & June 2005-December 2010 & $3 \mathrm{~km}$ (nadir) & Ocean \\
SeaWiFS & SeaWiFS & September 1997-December 2010 & $8 \mathrm{~km}$ & Ocean \\
SeaWiFS* & SeaWiFS & September 1997-December 2010 & $0.5^{\circ}$ & Ocean and land (including Sahara) \\
MERIS & ENVISAT & May 2002-February 2010 & $1^{\circ}$ & Ocean and land (except Sahara) \\
AVHRR & NOAA & January 1982-December 2007 & $0.5^{\circ}$ & Ocean \\
\hline TOMS & Nimbus-7 & January 1980-December 1992 & $1^{\circ}$ & Ocean and land (except Northern Europe) \\
CZCS & Nimbus-7 & October 1978-June 1986 & $8 \mathrm{~km}$ & Ocean \\
MVIRI & MeteoSat & June 1983-December 1997 & $0.4^{\circ}$ & Mediterranean Sea \\
TOMS & Earth-Probe & July 1996-December 2000 & $1^{\circ}$ & Ocean and land (except Northern Europe) \\
\hline
\end{tabular}

* Named SeaWiFS-2 in this study.

from both the standard and the Deep Blue algorithms, the whole Mediterranean region is covered by AQUA/MODIS and TERRA/MODIS.

The Multiangle Imaging SpectroRadiometer (MISR) is a passive radiometer also launched onboard the TERRA platform in 2000. MISR provides radiometrically and geometrically calibrated images at four wavelengths (446, 558, 672 and $866 \mathrm{~nm}$ ) in nine different directions (four forward, four backward, and nadir), both over land (desert included) and ocean (Kahn et al., 2005, 2010). In the present study, we use AOD from the Level-3 monthly aerosol products (MIL3MAE, version F15_0031). Like MODIS, MISR has the advantage to cover the whole basin and surrounding land surfaces over a long period (since 2000).

The POLarization and Directionality of the Earth's Reflectances (POLDER) instrument was launched onboard the PARASOL instrument in 2005 after two premature failures after 9 months of operations on the ADEOS-I and -II platforms (Tanré et al., 2001). This instrument retrieves aerosol optical and microphysical properties in a unique way thanks to its directional polarised measurements at 670 and $865 \mathrm{~nm}$ (Herman et al., 2005). PARASOL total AOD is only available over ocean (Tanré et al., 2011). We use the Level-3 monthly aerosol product (ATM_TAUA_M and ATM_ANG_M) to get $\mathrm{AOD}$, as well as the Angstrom exponent to calculate AOD at $550 \mathrm{~nm}$ following equation 1, in which $\alpha$ is the Angstrom coefficient, $\lambda$ and $\lambda_{0}$ two different wavelengths, and AOD the aerosol optical depth at these respective wavelengths. This calculation is necessary to compare all AOD products at the same wavelength, namely $550 \mathrm{~nm}$.

$\operatorname{AOD}(\lambda)=\operatorname{AOD}\left(\lambda_{0}\right)\left(\frac{\lambda}{\lambda_{0}}\right)^{-\alpha}$

The SEVIRI radiometer was launched on the Meteosat Second Generation (MSG) satellite, which is a geostationary satellite above longitude $0^{\circ}$. This enables to have a very high temporal resolution (images every $15 \mathrm{~min}$ ). A method was developed to retrieve AOD over ocean from SEVIRI measurements at 0.63 and $0.81 \mu \mathrm{m}$ (Thieuleux et al., 2005). The present work uses Level-2 monthly-averaged aerosol product (SEV_AER-OC-M3) downloaded from the ICARE data centre (http://www.icare.univ-lille1.fr), and available since June 2005.

The Sea-viewing Wide Field-of-view Sensor (SeaWiFS) is a multispectral ocean color sensor in the visible and near infrared (NIR) spectrum (Jamet et al., 2004; Wang et al., 2005). It provides both AOD and the Angstrom exponent, used in this study. As for PARASOL, equation 1 enables to get AOD at $550 \mathrm{~nm}$ from retrievals at $865 \mathrm{~nm}$. SeaWiFS has a long retrieval period (since 1997), but only covers ocean. Data was downloaded from the NASA ocean colour products website (http://oceancolor.gsfc.nasa.gov, level-3 monthly AOD and angstrom exponent). It is well-known that the standard aerosol product underestimates AOD in regions affected by desert dust because pixels affected by a turbid atmosphere are removed to insure the best quality of marine products which are the main goal of the SeaWiFS (Jamet et al., 2004) and because significant absorption in the blue by dust aerosol is neglected by the standard algorithm (Moulin et al., 2001). A more realistic AOD product has been produced from SeaWiFS over the Mediterranean for the period 1997-2004 (Antoine and Nobileau, 2006), but was not available for our study. More recently, a newly-developed AOD retrieval algorithm over land and ocean has been applied to SeaWiFS measurements (Hsu et al., 2012). It is based on a combination of the Deep Blue algorithm over land (Hsu et al., 2004) and the SeaWiFS Ocean Aerosol Retrieval (SOAR) algorithm over ocean (Sayer et al., 2012). This new product has been included in the present intercomparison (level-3 monthly AOD), and will be called SeaWiFS-2 in this paper. 
The Medium Resolution Imaging Spectrometer (MERIS) is a multi-spectral sensor launched onboard the ENVISAT satellite in 2002. MERIS retrieves aerosol properties in the 390 to $1040 \mathrm{~nm}$ spectral range over land and ocean (Antoine and Morel, 1999; Santer et al., 1999), but does not include bright surfaces like Sahara. In this study, we use the Level2 monthly aerosol product (MER_T550M) obtained with the Giovanni online data system.

The Advanced Very High Resolution Radiometer (AVHRR) included in the Pathfinder ATMOSphere (PATMOS) project provides a multiyear (1982-2007) multisatellite (NOAA-7, -9, -11 and -14) dataset (Stowe et al., 1997). The aim of PATMOS is to generate multiple products (cloud, aerosol, surface and radiometric) on the same grid using a common processing path. We use for this study the level-3 aerosol product (patmosx_aft_mor), downloaded from the PATMOS website (http://cimss.ssec.wisc.edu/patmosx/). AVHRR only covers ocean surfaces, but provides AOD data over the longest period (26 yr). All eight satellite-derived aerosol datasets listed above are extending up to 2010 (except for AVHRR to 2007). We also consider 3 more historical datasets, which cover the early 1980s, as listed below.

The Total Ozone Mapping Spectrometer (TOMS) onboard the Nimbus-7 satellite retrieves aerosol properties over land and water surfaces (Torres et al., 2002). These measurements rely on the near-UV region, and the aerosol index from TOMS is often used (Herman et al., 1997). In this study, we use monthly-averaged aerosol optical depth (globe_tau_MMMYY.asc files) downloaded from the NASA website (http://toms.gsfc.nasa.gov/aerosols/aot.html), which covers the 1980-1992 period. Even if data are retrieved over land and ocean, very few observations are available north of $35^{\circ} \mathrm{N}$ (Herman et al., 2001). After the end of Nimbus-7 in April 1993, TOMS was launched onboard the Earth-Probe satellite in July 1996, retrieving aerosols until 2005. Because of a deterioration of the instrument after 2000, only data between 1997 and 2000 has been included in the present work.

The Coastal Zone Colour Scanner (CZCS) onboard Nimbus-7 is a scanning radiometer viewing the ocean in six coregistered spectral bands (Hovis et al., 1980). It aims at providing estimates of the near-surface concentration of phyto-plankton pigments as well as aerosol properties over the sea surface as a by-product of the atmospheric-correction algorithm (Gordon and Wang, 1994). We use for this study the level-2 aerosol products (AOD at $865 \mathrm{~nm}$ and Angstrom exponent) available over the period 1978-1986 that include the oldest data in the present work. The Meteosat Visible and InfraRed Imager (MVIRI) was launched onboard the first generation of geostationary Meteosat satellites operated from late 1977 to late 2006 (Meteosat-1 to -7, www.eumetsat. int). Images were provided in three relatively wide spectral bands (solar, water vapour and thermal infrared channels), and the AOD is calculated from Meteosat solar radiances (Moulin et al., 1997a). Original Meteosat images obtained before June 1983 had unfortunately been lost to our knowledge and we use here time series from 1984 to 1997 provided by C. Moulin (Moulin et al., 1998). The spatial coverage concerns only the Mediterranean Sea (Black Sea included). To summarise only TERRA/MISR, AQUA/MODIS, TERRA/MODIS and SeaWiFS-2 sensors provide AOD over the whole Mediterranean basin. In that sense, our possible reconstruction of the AOD field must consequently be based on one or several of these four sensors. The others will be evaluated in this study and some of them can be useful to better assess the aerosol load over the Mediterranean region.

In addition to the atmospheric content, the aerosol vertical distribution is a critical property for aerosol-climate interactions. Apart from a short survey of the aerosol profile over the Mediterranean based on the LITE (Lidar In-space Technology Experiment) mission in September 1994 (Berthier et al., 2006), the only available long-term satellite product is provided by the Cloud-Aerosol Lidar with Orthogonal Polarization (CALIOP). This instrument onboard the Cloud Aerosol Lidar and Infrared Pathfinder Satellite Observations (CALIPSO) is a space based lidar system launched in 2006 (Vaughan et al., 2004; Winker et al., 2009). It allows to retrieve the vertical profiles of aerosol properties. We use here the level-2 LIDAR product (CALLIDL2, version 3.01) for the "Atmospheric_Volume_Description" variable, which indicates for each altitude (at a vertical resolution of $60 \mathrm{~m}$ ) the type of aerosol among the following ones: clean continental, polluted continental, dust, polluted dust, marine, smoke and unattributed. For this study, we have collected data from 2006 to 2010, namely every track of CALIPSO which has crossed the Mediterranean region.

\subsection{Model data}

As mentioned in the introduction, the present work also compares AOD from several model data, which consider five different aerosol types: soil dust, sea-salt, black carbon, organic carbon and sulfates. Table 2 summarises the model products (model, type of product, period of study, spatial resolution and coverage).

The climatology from (Tegen et al., 1997), named TEG97 in the present study, is a coarse resolution $\left(5 \times 3.9^{\circ}\right)$ monthly average aerosol distribution valid for the early $1990 \mathrm{~s} \mathrm{ob-}$ tained from a combination of global distributions of aerosols given by different transport models for soil dust (Tegen and Fung, 1995), sea-salt (Tegen et al., 1997), sulfates (Chin et al., 1996) and carbonaceous aerosols (Liousse et al., 1996). It has been used in several global and regional climate models such as ALADIN-Climate (Farda et al., 2010), in recent comparative works (Zubler et al., 2011c), as well as in numerical weather prediction models (e.g., Tompkins et al., 2005). Because of the coarse spatial resolution (T21), regional aerosol loads such as dust over Northern Africa are not well represented. However, compared to the oldest climatology of Tanré et al. (1984), this climatology has brought a sensitive 
Table 2. Main characteristics of the different model-simulated products used in this study.

\begin{tabular}{llrrl}
\hline $\begin{array}{l}\text { Based-model } \\
\text { products }\end{array}$ & Type & Period of study & $\begin{array}{r}\text { Spatial } \\
\text { Resolution }\end{array}$ & $\begin{array}{l}\text { Spatial } \\
\text { coverage }\end{array}$ \\
\hline TEG97 & Climatology & $1 \mathrm{yr}$ & $5 \times 3.9^{\circ}$ & Global \\
GEMS & Reanalysis (with AOD assimilation) & $2003-2008$ & $1.125^{\circ}$ & Global \\
MACC & Reanalysis (with AOD assimilation) & $2003-2010$ & $1.125^{\circ}$ & Global \\
LMDz-OR-INCA & Climate-chemistry model & $1850-2010$ & $3.75 \times 1.875^{\circ}$ & Global \\
RegCM-4 & Climate-chemistry model & $2000-2009$ & $50 \mathrm{~km}$ & Regional \\
ACCMIP & Climate-chemistry model mean & 1980 and 2000 & {$\left[1.24-3.75^{\circ}\right]$} & Global \\
\hline
\end{tabular}

improvement in global AOD (Tompkins et al., 2005; Zubler et al., 2011c).

The European Center for Medium-Range Weather Forecasts (ECMWF) has developed a reanalysis of global atmospheric composition since 2003, which includes the five main aerosol species. To constrain these aerosols, it includes the assimilation of the MODIS AOD at $550 \mathrm{~nm}$ (Remer et al., 2005) where available, namely not over bright surfaces (Benedetti et al., 2009). The first attempt (Morcrette et al., 2009), corresponding to the GEMS (Global and regional Earth-System (atmosphere) Monitoring using Satellite and in-situ data) project, covers the period 2003-2008. The Monitoring Atmospheric Composition and Climate (MACC) is the second version. It provides improvements in sulfate distributions and has extended the reanalysis to the 20032011 period (Kaiser et al., 2010; Benedetti et al., 2011).

RegCM-4 is a regional climate model (Giorgi et al., 2012), incorporating an interactive aerosol scheme. Assuming an external mixture, this scheme includes advection, diffusion by turbulence, vertical transport by deep convection, surface emissions, dry and wet removal processes and chemical conversion mechanisms (Qian et al., 2001; Solmon et al., 2006). Dust and sea-salt aerosols are emitted with generation modules (Zakey et al., 2006, 2008; Nabat et al., 2012), whereas anthropogenic aerosols emissions are related to inventories based on reference years. AOD like the other optical properties are computed off-line for each aerosol type using a Mie scattering code. The simulation used in this study (Nabat et al., 2012) covers the period 2000-2009, forced by ERA-INTERIM (Dee et al., 2011) as lateral boundary conditions, in order to have a realistic chronology. Dust outbreaks can, for example, be simulated accurately at the relevant date (Nabat et al., 2012).

LMDz-OR-INCA is an atmosphere general circulation model (LMDz, Hourdin et al., 2006) coupled with a chemistry-aerosol module (INCA: Interactions between Chemistry and Aerosols, Hauglustaine et al., 2004). It includes the five aerosol species mentioned before. The simulation and the set-up used in this study are described in Szopa et al. (2013). The 1850-2100 period is covered, including a historical period (1850-2000) with reference aerosol emissions (Lamarque et al., 2010), and a future projection ac- cording to the representative concentration pathway (RCP 4.5) projection for greenhouse gases emissions (Thomson et al., 2011). As we consider only the period until 2010 for the present work, the choice of the projection does not have any influence on the aerosol atmospheric content, as AOD is similar in the four scenarios between 2000 and 2010 (Szopa et al., 2013). Contrary to the simulation of RegCM-4, no relaxation towards reanalysis is applied leading to an unreal (random) chronology in the aerosol events: only the statistics (variance, extrema,...) in AOD are correct. The quality of this climatology will also reflect that of the other atmospheric fields (notably wind and precipitation). However, the reference aerosol emissions over the historical period are of the utmost interest to study the trend in aerosol load over a long period due to emission and global climate changes (Lamarque et al., 2010). Besides, this model has taken part in the model inter-comparison AeroCom initiative, showing a global average AOD close to the median AOD of all the global models (Kinne et al., 2006).

The Atmospheric Chemistry and Climate Model Intercomparison Project (ACCMIP) has gathered several chemistry-climate and chemistry-transport models, in order to study the long-term changes in atmospheric composition between 1850 and 2100 (Lamarque et al., 2013). This exercise includes longer simulations than AeroCom, with compulsory time-slices (notably 1980 and 2000). The mean of models which have interactive aerosols, namely CICERO-OsloCTM2 (Skeie et al., 2011), GFDL-AM3 (Donner et al., 2011), GISS-E2-R (Shindell et al., 2013b), GISSE2-R-TOMAS (Lee and Adams, 2010), HadGEM2 (Collins et al., 2011), LMDz-OR-INCA (Szopa et al., 2013), MIROCCHEM (Watanabe et al., 2011), NCAR-CAM3.5 (Lamarque et al., 2012) and NCAR-CAM5.1 (Liu et al., 2012), has been included as a participant in the present intercomparison. The AOD trends between 1980 and 2000 have also been investigated for each of these models.

To sum up GEMS and MACC combine model results and observations (MODIS AOD) and, thus, contain a priori more information than the other products. However, both the interactive scheme of RegCM-4 for dust and seasalt aerosols associated with realistic boundary forcings from ERA-INTERIM and the multi-year simulations of 
LMDz-OR-INCA (1850-2010) and the ACCMIP models (timeslices 1980 and 2000) could also be helpful in producing the desired long-term reconstruction of the AOD distribution of the various aerosol types over the Mediterranean region.

\subsection{Ground-based measurements}

In-situ aerosol observations are useful to evaluate satellitederived and model-simulated AOD. AERONET is a groundbased globally distributed network of automatic Sun/sky radiometers (Holben et al., 1998, 2001). The aerosol microphysical (volume size distribution) and optical (single scattering albedo, refractive index and asymmetry parameter) properties can be retrieved for the whole atmospheric column following the methodology proposed by Dubovik et al., 2002. For the present work, we have only used AOD monthly average quality-assured data (Level 2.0) downloaded from the AERONET website (http://aeronet.gsfc. nasa.gov). Angstrom exponent was also downloaded in order to calculated AOD at $550 \mathrm{~nm}$ from measurements at 440 or $500 \mathrm{~nm}$ (see Eq. 1). As the main interest of the paper is the Mediterranean region, all the stations located in the area from 28 to $47^{\circ} \mathrm{N}$ and from $8^{\circ} \mathrm{W}$ to $37^{\circ} \mathrm{E}$ have been selected, provided the measurements cover a period of at least one year. Figure 1 shows the 47 corresponding stations. It should be noticed that most stations are situated in continental Europe and that the African region is under-represented.

\section{Comparison and evaluation}

\subsection{Methodology}

The different satellite and model monthly AOD products are evaluated for each station when both AERONET and satellite-derived (and model-simulated) AOD are available. Every dataset is averaged over a $1 \times 1^{\circ}$ box around the AERONET site. This method enables to include in the comparison products which cover only ocean surfaces thanks to coastal AERONET stations. Results based on temporal and spatial correlations will be both presented in Taylor diagrams (Taylor, 2001), which indicate how closely a pattern matches observation representing three statistics, namely the correlation coefficient (indicated by the azimuthal angle), the standard deviation normalised by the observed standard deviation (the radial distance from the origin) and the root-meansquare (RMS) difference (the distance to the point on the $\mathrm{x}$ axis identified as "observed"). In our case, given the high number of stations and datasets for evaluating temporal correlation, the ensemble of points representing all stations is included in a polygon for the corresponding dataset. The cross (resp. the diamond) indicates the average for the corresponding satellite (resp. model). In the same way, for evaluating spatial correlation, polygons include the ensemble of points representing the different months for the correspond-

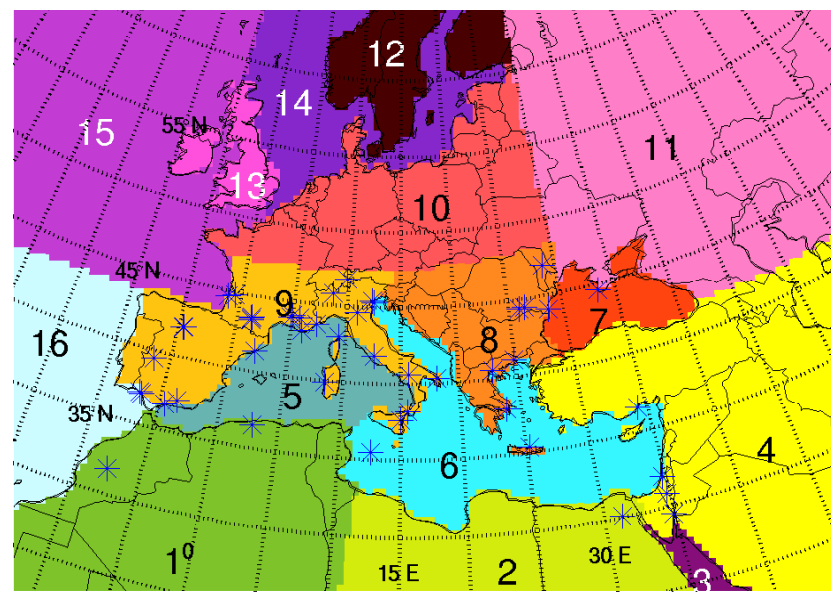

Fig. 1. Domain of study over the Mediterranean basin. The 47 studied AERONET stations are indicated with a blue star. Colours on the map define regions (numbered from 1 to 16) for applying regionaveraged CALIOP aerosol vertical profiles in the final AOD field product (see Sect. 3.4 and Table 4).

ing dataset. Box and whisker plots are also used to characterise the biases of AOD products against AERONET measurements. The median will be indicated as a thick black line while the central box will be limited by the first and third quartile. The whisker limits will correspond to the inner quartile range multiplied by 1.5 . All the points out of this range (outliers) will be indicated with small circles.

\subsection{Total AOD}

\subsubsection{Satellites}

The common period for all the recent (in the 2000s) datasets covers only two years (2006-2007), which turns out to be very short. For this reason we have decided to use the whole period of time for every dataset, especially as very few differences are noticed using 2006-2007 instead of the whole time period (figure not shown). Table 3 presents the corresponding period of time for each dataset, as well as averages on the European continent (region $8+9+10$ in Fig. 1), the Mediterranean Sea $(5+6)$ and Northern Africa $(1+2)$ over the mentioned period. Figures 2 and 3 present the averaged AOD map at $550 \mathrm{~nm}$ over the Mediterranean basin, respectively, for the different satellite and model datasets. Averages over the common period 2006-2007 are also indicated between brackets in Table 3. The two means over the period of study for each dataset and the common period are found to be very close in most cases.

Large differences can be noticed between these sensors in Fig. 2, but a relative agreement can be found between MODIS (on AQUA and TERRA) and MISR. These three products which cover the whole domain show the same geographical structure and their averages in Table 3 are very close. The maximal AOD, related to dust aerosols, is 
Table 3. Averaged AOD at $550 \mathrm{~nm}$ over the European continent (region $8+9+10$ ), the Mediterranean Sea (region $5+6)$ and Northern Africa (region 1+2) for each satellite-derived and model-simulated product. Averages are calculated over the period of study (second column) for each dataset. Averages over the 2006-2007 common period are also indicated (between brackets), except for TEG97 and ACCMIP which do not have interannual variability

\begin{tabular}{lrrrr}
\hline Dataset & Averaged period & Europe & Mediterranean Sea & Northern Africa \\
\hline AQUA/MODIS & $2003-2010$ & $0.144(0.147)$ & $0.197(0.198)$ & $0.273(0.275)$ \\
TERRA/MODIS & $2001-2010$ & $0.151(0.148)$ & $0.206(0.207)$ & $0.298(0.309)$ \\
TERRA/MISR & $2001-2010$ & $0.140(0.141)$ & $0.211(0.208)$ & $0.272(0.267)$ \\
PARASOL/POLDER & $2006-2010$ & - & $0.244(0.259)$ & - \\
MSG/SEVIRI & $2006-2010$ & - & $0.185(0.176)$ & - \\
SeaWiFS & $2000-2007$ & - & $0.111(0.114)$ & - \\
SeaWiFS-2 & $2000-2007$ & $0.154(0.150)$ & $0.168(0.165)$ & $0.261(0.260)$ \\
ENVISAT/MERIS & $2003-2010$ & $0.276(0.280)$ & $0.151(0.146)$ & - \\
NOAA/AVHRR & $2000-2007$ & - & $0.179(0.180)$ & - \\
\hline TEG97 & - & 0.176 & 0.196 & 0.174 \\
GEMS & $2003-2008$ & $0.249(0.248)$ & $0.244(0.238)$ & $0.339(0.330)$ \\
MACC & $2003-2010$ & $0.195(0.198)$ & $0.239(0.239)$ & $0.260(0.255)$ \\
RegCM-4 & $2000-2009$ & $0.127(0.129)$ & $0.192(0.187)$ & $0.291(0.279)$ \\
LMDz-OR-INCA & $2000-2010$ & $0.183(0.178)$ & $0.235(0.236)$ & $0.405(0.409)$ \\
ACCMIP & 2000 & 0.205 & 0.231 & 0.316 \\
\hline
\end{tabular}

observed over Northern Africa (averaged AOD between 0.27 and 0.30) and Near-East. These three retrievals over Sahara underline more precisely large AOD over Eastern Algeria, Tunisia and Libya, which are dust sources already identified by Laurent et al. (2008) where annual average AOD can exceed 0.4. Over the sea, AOD is evaluated between 0.19 and 0.21 , and a North-South AOD gradient is well established $\left(0.65 \times 10^{-2}\right.$ per latitude degree $\left(/^{\circ}\right)$ for AQUA/MODIS and TERRA/MODIS, $0.49 \times 10^{-2} / 0$ for TERRA/MISR). In Europe, AOD is lower (0.14 to 0.15 ), except in urban and industrial areas such as the Po Valley (up to 0.26 with MODIS). However, the sea-land contrast is more visible in MISR AOD (e.g., the Black Sea), probably revealing problems in surface reflectances. The other difference between MISR and MODIS concerns the Near-East, where AOD is stronger in MODIS. SeaWiFS-2 AOD also presents the same patterns as MODIS and MISR, but its local maxima over Benelux and the British Isles are higher.

The other sensors do not cover the land area or the Saharan desert, but can still bring some information. AVHRR, SEVIRI and PARASOL show a representation of the AOD variability over the Sea similar to MODIS and MISR, with maximum values in South-Eastern sea and smaller AOD in the Gulf of Lions. Although they do not retrieve aerosols over continental surfaces, thus, limiting their use in a possible regional aerosol climatology for RCM simulations, SEVIRI onboard the MSG geostationary satellite has yet an excellent temporal and spatial resolution. Its average AOD over the Sea (0.185) is slightly lower than MODIS and MISR, and its AOD north-gradient slightly higher $\left(0.85 \times 10^{-2} /{ }^{\circ}\right)$. PARASOL has by far the highest AOD over the sea $(0.244)$ and the highest north-south gradient $\left(1.45 \times 10^{-2} /{ }^{\circ}\right)$ among all the sensors, which might reveal a positive bias, especially over the Eastern basin. With regards to MERIS and SeaWiFS, the comparison clearly shows their limitations. MERIS has an unrealistic sea-land contrast, as continents can be clearly identified on the AOD map. It is the only one among the sensors to show an average AOD higher (and by far) over continental Europe (0.276) than over the sea (0.151). SeaWiFS AOD is much lower than the other satellite products $(0.11$ over the Mediterranean Sea), with a lower north-south gradient $\left(0.28 \times 10^{-2} /^{\circ}\right)$. This possible underestimation can be attributed to the rejection by the operational algorithm of every pixel where reflectance is above a certain threshold corresponding to an AOD larger than 0.35 in order to assure the quality of the retrieved marine parameters which are the main objective of the SeaWiFS mission (Jamet et al., 2004). The same conclusion for the SeaWiFS AOD has been drawn by Myhre et al. (2005). Comparison between all these satellite AOD and AERONET estimations are discussed below.

\subsubsection{Models}

Total AOD can also be provided by global or regional model products. Figure 3 presents the annually averaged AOD map at $550 \mathrm{~nm}$ over the Mediterranean basin taken from the five model-simulated products (see Table 2). TEG97, which is the oldest product of our selection, clearly differs from the other data. No maximum over Northern Africa can be identified resulting in a low north-south AOD gradient $\left(0.32 \times 10^{-2} /{ }^{\circ}\right)$, whereas a strong West-East AOD contrast can be noticed, due to sulfate aerosols in central Europe. As a result, the averages over Europe (0.176), the sea (0.196) and Northern Africa (0.174) are very close. The ACCMIP 


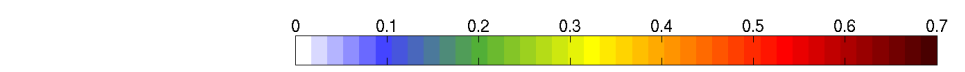

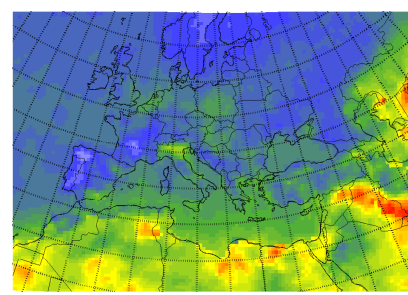

(a) - AQUA/MODIS (2003-2010)

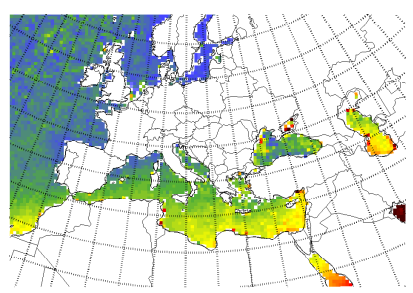

(d) - PARASOL (2006-2010)

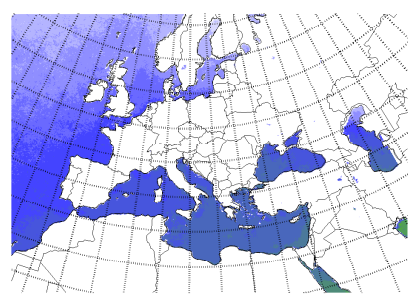

(g) - SeaWiFS (2000-2010)

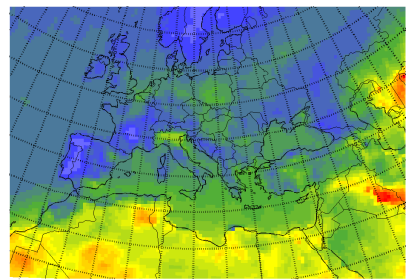

(b) - TERRA/MODIS (2001-2010)

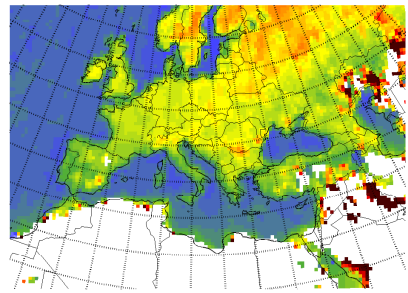

(e) - ENVISAT/MERIS (2003-2009)

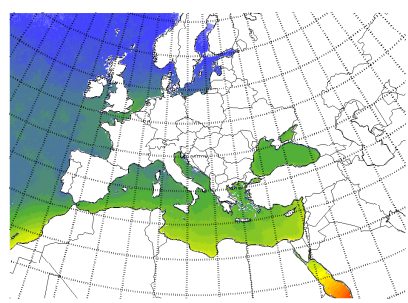

(h) - MSG/SEVIRI (2006-2010)

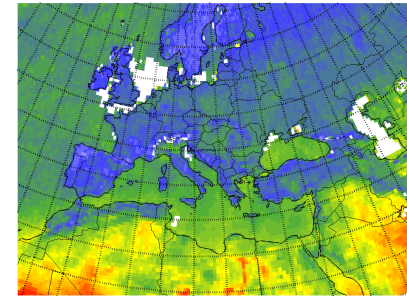

(c) - TERRA/MISR (2001-2010)

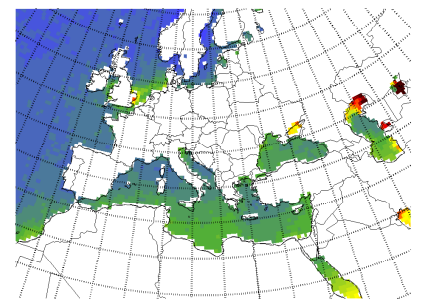

(f) - NOAA/AVHRR (2000-2007)

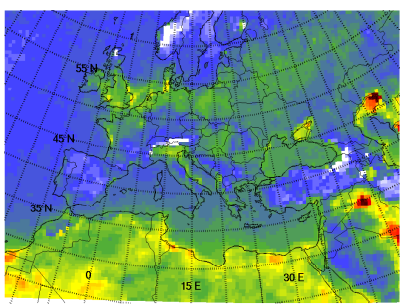

(i) - SeaWiFS-2 (2000-2010)

Fig. 2. Mean Aerosol Optical Depth (AOD) at $550 \mathrm{~nm}$ from different satellite sensors over the Mediterranean region.

mean, LMDz-OR-INCA and RegCM-4 show a spatial structure closer to satellite-derived products, with a maximum over Sahara and a North-South gradient over the Sea (respectively $0.50,0.84$ and $0.81 \times 10^{-2} /{ }^{\circ}$ ). However, the AOD in LMDz-OR-INCA is shown to be higher than in other datasets for the three studied regions of Table 3 (Europe, Mediterranean Sea and Northern Africa), especially over Northern Africa (0.403). RegCM-4 AOD over the Mediterranean Sea (0.178) and Northern Africa (0.257) is closer to MODIS and MISR AOD averages, but slightly lower. In Europe, RegCM$4 \mathrm{AOD}(0.127)$ is lower than in satellite datasets, particularly in western Europe (Benelux, Germany, Po Valley), suggesting a possible underestimation of AOD due to a lack of anthropogenic aerosols (sulfates, see Sect. 3.3). This would also explain the slight difference over the Mediterranean Sea and Africa where sulfate aerosols are less important. Over the Atlantic Ocean, low AOD simulated in RegCM-4 compared to satellite datasets may be due to the proximity of this region to the limit of the domain, thus, missing in RegCM-4 simulation aerosols produced over the Atlantic Ocean outside the domain. GEMS and MACC have also a similar spatial distribution of AOD. The AOD assimilation enables them not to be far from MODIS products. However, GEMS AOD is larger over Europe ( 0.245 on average), linked to an overes- timation of sulfate aerosols over Central Europe, related to a bug in the conversion from $\mathrm{SO}_{2}$ to $\mathrm{SO}_{4}$ corrected in the MACC version (Morcrette et al., 2011). Over the Sea (0.243) and Northern Africa (0.335), its AOD is also higher than in most other datasets. MACC is the second version of the ECMWF reanalysis and has reduced the difference over Europe (0.194), but still have a high AOD over the Sea (0.238). Over Northern Africa, MACC (0.257) has a lower AOD than GEMS (0.335), and also smaller than other datasets in this region of dust production. Over the bright surfaces of Sahara where MODIS AOD is not assimilated, GEMS and MACC have to rely on the model dust emission parameterisation, which was revised downward for MACC when GEMS was assessed to produce too high an AOD for dust aerosols (Mangold et al., 2011; Morcrette et al., 2011). ACCMIP AOD is similar to MACC over Europe (0.205) and the Mediterranean Sea (0.231), and higher than satellite data sets over Northern Africa (0.316).

\subsubsection{Comparison of seasonal cycle}

The aerosol atmospheric content is submitted to a strong seasonal cycle over the Mediterranean region (Moulin et al., 1998; Barnaba and Gobbi, 2004) and this seasonal variability 


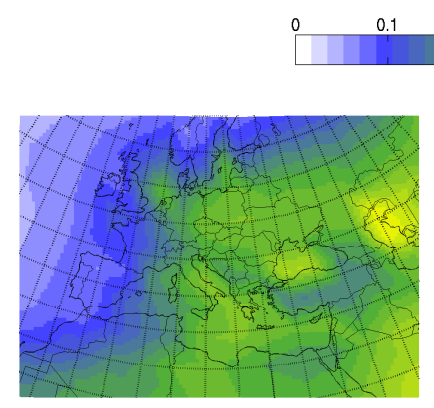

(a) - TEG97

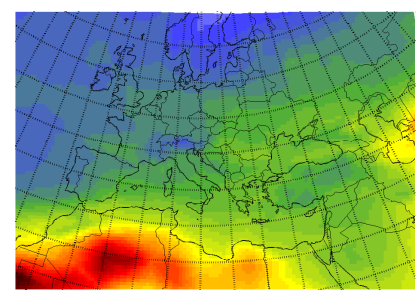

(d) - LMDz-OR-INCA (2000-2010)

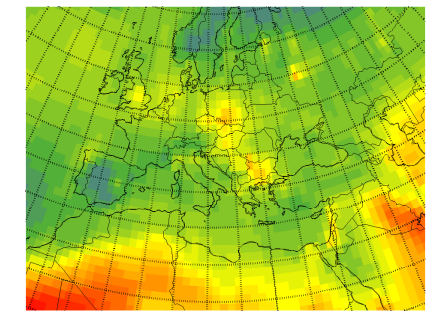

(b) - GEMS (2003-2008)

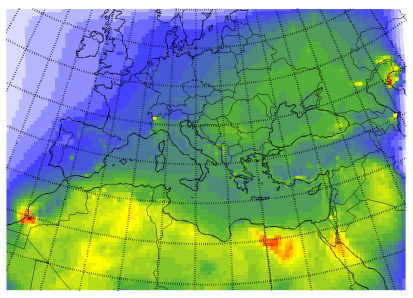

(e) - RegCM-4 (2003-2009)

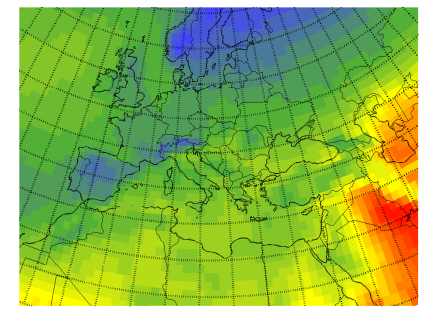

(c) - MACC (2003-2010)

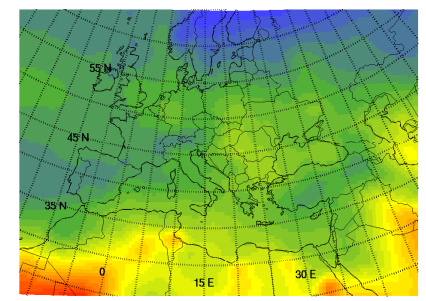

(f) - ACCMIP (2000)

Fig. 3. Mean Aerosol Optical Depth (AOD) at $550 \mathrm{~nm}$ from different model-simulated products over the Mediterranean region.
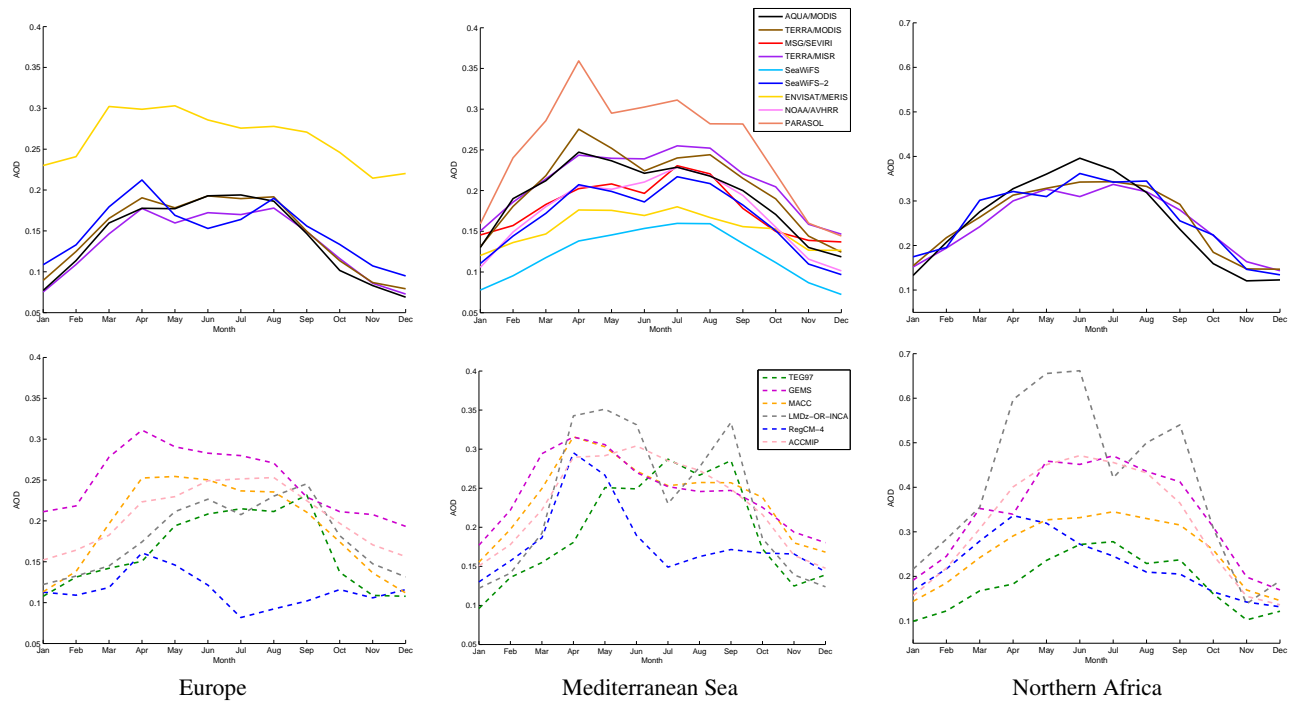

Fig. 4. AOD monthly averages at $550 \mathrm{~nm}$ for each dataset (top: satellites, bottom: models) over the European continent (region $8+9+10$ ), the Mediterranean Sea (region 5+6) and Northern Africa (region 1+2).

is now evaluated for the different datasets. Figure 4 shows the AOD monthly averages at $550 \mathrm{~nm}$ over the same studied regions for satellite-derived (top) and model-simulated (bottom) products. All of them present a seasonal cycle with a maximum in spring or summer and a minimum in winter, but with various amplitudes. Mediterranean AOD is indeed controlled by the dust emissions over Northern Africa (Moulin et al., 1998), with a maximum in spring and summer, and anthropogenic aerosols in summer over Central Europe (Barnaba and Gobbi, 2004). Deposition also favours this summer maximum, as winds and rainfall increasing aerosol deposition are stronger in winter than in summer. Among the satellite products, monthly averages over the Sea show a strong similarity between MODIS (on AQUA and TERRA) and MISR, even if TERRA/MODIS AOD is lower in spring and AQUA/MODIS AOD in summer. The same variations but with a positive difference compared to MODIS and MISR are shown by PARASOL, as well as by SEVIRI, SeaWiFS-2 and AVHRR with a negative difference. In parallel, MERIS and SeaWiFS show less difference in AOD between winter and summer. Concerning models, GEMS, MACC and ACCMIP are able to reproduce this AOD variability over the 


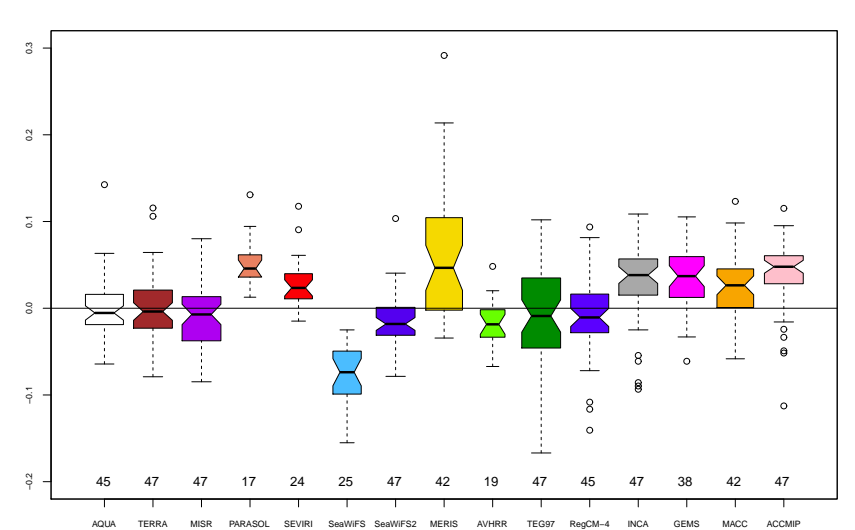

Fig. 5. Box-and-whisker plots (median, first and third quartile, outliers, more details in Sect. 3.1) representing the bias between monthly-averaged AERONET observations and the different satellite-derived and model-simulated products. Calculations have been realised between 1999 and 2010 for 47 stations over the Mediterranean basin. The numbers above the y-axis indicate the sample set (number of stations) used for the comparison (PARASOL, SEVIRI, SeaWiFS and AVHRR products are only over the sea).

Sea, as well as the other models to some extent. This was expected for GEMS and MACC which include MODIS AOD assimilation. TEG97 only captures the summer maximum, but not the spring one, probably because of the lack of dust aerosols. LMDz-OR-INCA cycle is disturbed by its strong dust emissions over Africa, which lead to two peaks in May and September which might be overestimated compared to other datasets. RegCM-4 is similar to satellite products before summer, when sulfate aerosols begin to have a significant role. Over Europe, differences between MODIS (on AQUA and TERRA), and MISR do not exceed 0.02 for every month revealing a very good agreement between these sensors, SeaWiFS-2 shows similar AOD variations and values except a minimum in June, while MERIS AOD is higher on average. TEG97, ACCMIP and LMDz-OR-INCA are quite similar to these three satellite sensors. GEMS presents the same variations, but with a positive difference compared to MODIS and MISR, which has been reduced in the MACC version. RegCM-4 clearly misses aerosols in summer compared to all the other datasets. Over Northern Africa, the seasonal cycle is still similar between both MODIS platforms, MISR and SeaWiFS-2. AOD peaks at 0.44 in summer in AQUA/MODIS and TERRA/MODIS, 0.40 in MISR and 0.36 in SeaWiFS-2. The models show different variations and values with a maximum situated between April and July, except LMDz-OR-INCA with these two peaks mentioned before which reach 0.66 over Africa.

\subsubsection{Comparison to AERONET}

After this comparison, we resort to independent groundbased measurements in order to evaluate these different
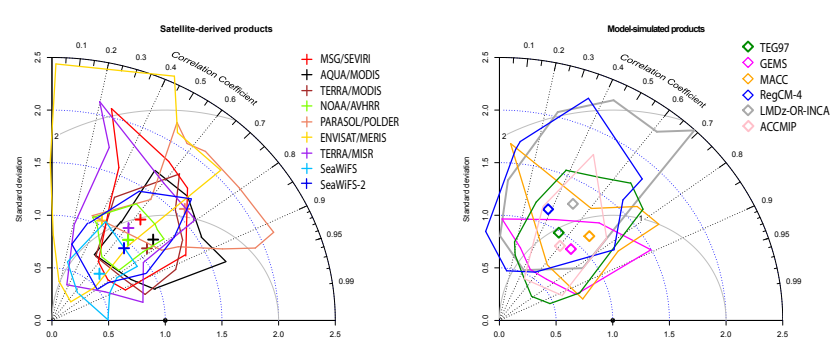

Fig. 6. Taylor diagrams evaluating satellite data (left) and model data (right) against AERONET observations in terms of temporal correlation for 47 stations around the Mediterranean basin.

AOD products. The AERONET network provides standardised high quality aerosol measurements and is used here as reference data. Comparison with satellite and model data is achieved for total AOD at $550 \mathrm{~nm}$ over the 47 stations available throughout the Mediterranean basin (Sect. 2.3, Fig. 1). Figure 5 presents the box-and-whisker plot as far as the bias between different datasets and AERONET observations is concerned. Results are averaged for every station considering all months having coincident satellite or model and AERONET AOD. The width of the box of each dataset is proportional to the sample size (number of stations) considered in the study, which is indicated above the yaxis. The maximum is 47 for model and satellite products with land and sea coverage. AERONET data are not available to be compared to historical TOMS, CZCS and MVIRI products.

Amongst satellite datasets, the median bias is close to 0 for AQUA/MODIS $(-0.005)$ and TERRA/MODIS $(-0.004)$, as well as for MISR (-0.007). However, AQUA/MODIS has the smallest box indicating a lower spread (one outlier point excepted in Sede-Boker, Israel) than TERRA/MODIS and MISR. The two outliers for TERRA/MODIS are also in Near-East (Sede-Boker and Eilat), which must be a region where MODIS has more difficulties to retrieve AOD. Over the sea, AVHRR has also very good AOD retrievals with low median bias $(-0.019)$ and spread. The other satellite sensors show larger errors in averaged AOD compared to AERONET, especially MERIS and SeaWiFS. SeaWiFS-2 has, however, significantly improved compared to the first version: its median is -0.018 against -0.074 for SeaWiFS. With regards to model-simulated products, TEG97 and RegCM-4 show a reduced median bias, -0.009 and -0.011 , respectively, but the spread is lower for RegCM-4. LMDzOR-INCA, GEMS, MACC and ACCMIP biases are slightly higher. We can also mention that RegCM-4, LMDz-ORINCA and ACCMIP show several outliers, which come from several points near the Alps as well as from Cairo.

Spatial and temporal correlations with AERONET observations are now evaluated, and the results are presented in Taylor diagrams, as detailed in Sect. 3.1. Figure 6 evaluates temporal correlation at every AERONET station (averaging 

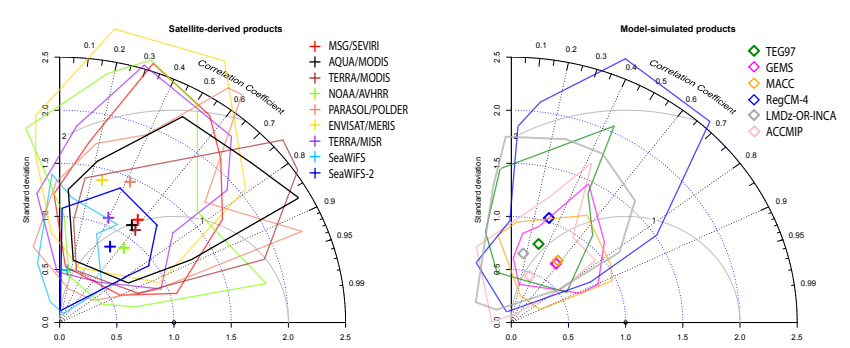

Fig. 7. Taylor diagrams evaluating satellite data (left) and model data (right) against AERONET observations in terms of spatial correlation for 47 stations around the Mediterranean basin.

all months available at the given station) for the different datasets. MODIS (on AQUA and TERRA) have the smallest average root-mean-square error (RMSE) among satellite datasets, as well as the highest correlation (respectively 0.76 and 0.77). Moreover, their spread is similar and not so large compared to the other datasets. Over the sea, PARASOL also shows a good correlation (0.74), but its standard deviation is much higher (59\%) than that of AERONET. AVHRR has the best estimated standard deviation and a very small spread, but a lower correlation (0.66) than MODIS. The other datasets show lower scores in the Taylor diagram, even for MISR. Large polygons for MERIS, MISR, SEVIRI and PARASOL indicate strong errors at some stations contrary to MODIS whose data are more homogeneous. SeaWiFS is the only one to show much too little variability, but a significative improvement is noticed with SeaWiFS-2. With regards to model datasets, MACC and GEMS reanalyses have the best RMSE and correlations, even if it should be noted that the evaluation against MODIS data is not completely independent because of data assimilation in these reanalyses. ACCMIP correlation is slightly lower (0.60), and larger errors are observed for TEG97, LMDz-OR-INCA and RegCM-4. Figure 7 presents the evaluation in terms of spatial variability for every month (i.e., averaging all stations for the given month). Four satellite-derived products (AQUA/MODIS and TERRA/MODIS, SEVIRI and AVHRR) have the highest correlation (around 0.6). Among them, AVHRR and SEVIRI have a wider spread than both MODIS. With regards to standard deviation, these four products as well as MISR and SeaWiFS-2 are close to AERONET. The other sensors, namely MERIS, SeaWiFS and PARASOL show lower scores, and a similar improvement between SeaWiFS and SeaWiFS-2 can be noticed both in terms of correlation and standard deviation. GEMS and MACC reanalysis reach the same correlation than the best satellite sensors, and have a smaller spread, but their standard deviation is too low by about $30 \%$. RegCM-4 shows a better standard deviation, but with a correlation of only 0.32 probably linked to a deficient description of the emission of anthropogenic aerosols in Central Europe (Nabat et al., 2012). TEG97, LMDz-OR-INCA and ACCMIP are not as accurate as the other models, which might be due to their coarser spatial resolution.

To summarise, this evaluation with ground-based measurements indicates that MODIS has the best AOD estimation for several criteria, in agreement with the evaluation at the global scale by Bréon et al. (2011). It is more difficult to choose between AQUA and TERRA as they show very similar results. Figure 5 has shown a more reduced spread for the AQUA/MODIS dataset than for the TERRA platform. Besides, Fig. 13c, which presents AOD averages over Northern Africa, shows that AQUA/MODIS has the same annual variations between 2003 and 2010 than MISR, MACC and GEMS, whereas TERRA/MODIS variations differ (notably with the peak in 2005). Besides, Levy et al. (2010) have recently underlined discovered issues with TERRA (notably an increasingly lower AOD since 2005). They have also shown at the global scale for dark-target products over land that Terra AOD presented a negative trend compared to AERONET measurements while comparisons between AERONET and Aqua AOD have shown no trend. For those reasons, AQUA/MODIS seems to be more trustworthy and we finally choose to use it for our reconstruction. Despite the evaluation, we are aware that this choice may be questionable and may evolve in future depending on product improvements.

\subsection{Separation by aerosol type}

Due to their different optical and microphysical properties, aerosol type discrimination is required for a reconstruction of aerosol climatology for a regional climate modelling purpose. Some satellite sensors provide a distinction between fine and coarse modes (e.g., Tanré et al., 1997; Anderson et al., 2005), but only model-based products can realise such apportionment of the total AOD. Given the evaluation shown in the previous paragraph, MACC has proved to have the best total AOD estimation among model products in terms of spatial and temporal correlation, but with a higher bias than TEG97 and RegCM-4. This section presents the characteristics of the different aerosols considered separately in each model in order to choose and retain the most relevant model dataset for every aerosol type in our reconstruction.

Figure 8 presents the AOD averages over three regions (Northern Africa, the Mediterranean Sea and Europe) for the previous models and each of the five aerosol types. The dust cycle with a maximum in spring and summer is simulated by each model with a varied intensity. Over Africa where aerosols are essentially composed by soil dust (SD), RegCM-4 AOD is very close to MODIS while TEG97 and MACC AOD is lower, ACCMIP, LMDz-OR-INCA and GEMS higher (see Table 3). Dust AOD over Africa shown in Fig. 8 can explain these differences. RegCM-4 dust AOD peaks at 0.34 in spring, with an average of 0.24 . The multimodel ACCMIP mean gives similar values for dust AOD ( 0.21 on average, with a monthly maximum at 0.34 in June). 

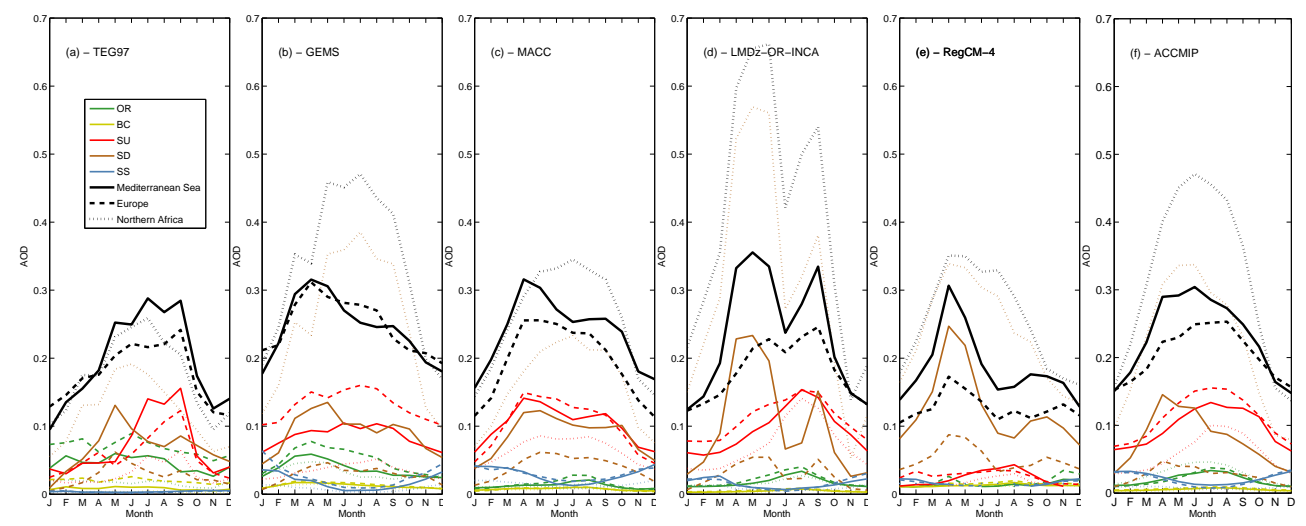

Fig. 8. Mean Aerosol Optical Depth (AOD) at $550 \mathrm{~nm}$ for each aerosol type $(\mathrm{SD}=$ soil dust, $\mathrm{BC}=$ black carbon, $\mathrm{OR}=$ organic carbon, $\mathrm{SU}$ = sulfates and SS = sea-salts) simulated by different models over the Mediterranean region. Averages are calculated over Northern Africa (dotted line), the Mediterranean Sea (continuous line) and Europe (dashed line). The black lines plot the total AOD for the different regions.

In contrast, MACC and TEG97 dust AOD only peak respectively at 0.19 and 0.23 underestimating dust emissions, while GEMS and especially LMDz-OR-INCA are much higher (maximum respectively at 0.39 and 0.58 ), overestimating dust emissions. As a result, RegCM-4 must be the best model with regards to dust load. This is not really surprising as this model, forced by a real chronology (the reanalysis ERA-INTERIM), has an interactive module to generate dust aerosols at a $50 \mathrm{~km}$ resolution (Zakey et al., 2006). This on-line approach to calculate high resolution dust fields has shown to produce realistic representations of dust outbreaks (Zakey et al., 2006; Solmon et al., 2008; Nabat et al., 2012), as well as dust AOD seasonal and regional variability over the basin. Moreover, MACC and GEMS cannot assimilate AOD over Africa contrary to the rest of the domain. A reasonable option is consequently to consider RegCM-4 AOD to estimate dust aerosols over the basin in our reconstruction.

As far as sea-salt (SS) aerosols are concerned, all modelbased products except TEG97 show a maximum in winter probably due to stronger winds over the Mediterranean Sea. These five models (RegCM-4, LMDz-OR-INCA, the ACCMIP mean, GEMS and MACC) have similar SS AOD, whose winter maximum ranges from 0.02 to 0.04 . Given these low AOD values and the small differences between these datasets, the choice is difficult and will not really affect the final reconstruction. As RegCM-4 presents the advantage to have an interactive module to generate SS aerosols at a $50 \mathrm{~km}$ resolution (Zakey et al., 2008) as for dust aerosols, this model should be a relevant choice for SS AOD in our reconstruction.

With regards to the other aerosols, differences between datasets are more important. Sulfate (SU) aerosols are prevailing, with a maximum in Central Europe during spring and summer, which is reproduced by every model. However, the intensity of this maximum differs. SU AOD over Europe peaks at 0.04 in RegCM-4, 0.12 in TEG97, and an agreement between 0.15 and 0.16 can be found in GEMS, MACC,
LMDz-OR-INCA and ACCMIP. Over the sea, the same variations can be observed. Given the better scores reached by MACC in terms of spatial and temporal correlation compared to AERONET stations which are more numerous in Europe, we can assess than RegCM-4 probably underestimates sulfate aerosols over the Mediterranean region. Additional tests (not displayed here) have shown a clear underestimation of sulfate production by RegCM-4 in this specific set of runs, due notably to an underestimation of both $\mathrm{SO}_{2}$ emissions and summer oxydant field prescribed as a climatology. Organic carbon (OR) have lower AOD, ranging from 0.02 (MACC and ACCMIP) to 0.07 (TEG97) on annual average over Europe. All models agree on the very low AOD for black carbon (BC) aerosols, estimated between 0.01 and 0.02 over Europe. For the same reason as for sulfate aerosols, we can be confident in MACC carbonaceous emissions which are similar to most other datasets. Given this good performance of MACC product over anthropogenically dominated European regions, we choose to represent sulfate, black and organic carbon AOD in our reconstruction from the MACC dataset.

Regarding these results, our reconstruction will be based on the products which provide the best AOD estimation, with respect to each aerosol type: SU, OR and BC from MACC, SD and SS from RegCM-4 (more details will be given in Sect. 4.1). MACC has got the best scores against AERONET observations, but this is essentially true for anthropogenic aerosols where enough AERONET stations are present. Over Africa the lack of desert dust aerosols in MACC has been identified with satellite datasets, and could cause problems for studies over the Mediterranean basin. The generation module of RegCM-4 for dust and sea-salt aerosols at a high resolution could be a relevant alternative. Again it should be stressed that other choices might be possible. Here the objective is mainly to present one way among others to develop a 4-D-reconstruction of AOD field over the Mediterranean area. 


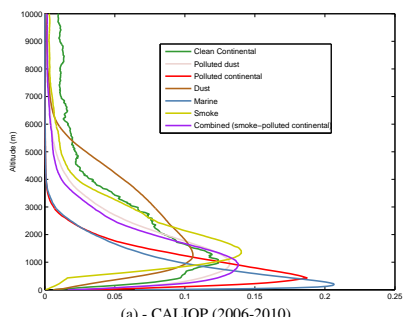

(a) - CALIOP (2006-2010)

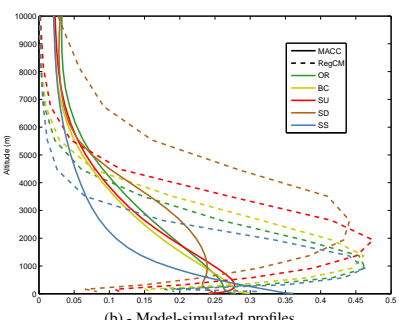

(b) - Model-simulated profiles
Fig. 9. Mean aerosol type vertical profile over the Mediterranean basin. CALIOP (2006-2010) on the left, model-simulated products on the right (MACC in continuous line, RegCM-4 in dashed line).

\subsection{Vertical dimension}

Up to this point the present work has focused on the bidimensional temporal representation of aerosols. Their vertical distribution must also be investigated since it has been identified as a major source of uncertainties in the simulation of aerosol processes (Textor et al., 2006). For the time and to our knowledge, the CALIOP instrument represents the best way to assess the vertical profiles of particles at regional scale, including an aerosol speciation. Such information on the aerosol type is not available from surface lidar (EARLINET) or sun-photometer (AERONET) observations. Figure 9 presents the mean vertical profiles of different aerosol types from CALIOP (left) and from MACC and RegCM-4 (right), the two coupled-chemistry models of our study that simulate such a vertical distribution, averaged over the Mediterranean basin (see Fig. 1). For CALIOP, the profile results from counting each aerosol type identified at a given altitude over the basin. Profiles from both CALIOP and models are normalised to the total number of identifications of each aerosol type in order to focus only on its relative vertical distribution. The direct comparison of vertical profiles of CALIOP aerosol types with those of different aerosol components simulated by the models is only possible for CALIOP Marine and Dust aerosol types which can be associated to model sea-salt (SS) and soil dust (SD). Sulfates, OR and $\mathrm{BC}$ have multiple sources and should be found simultaneously in the other CALIOP aerosol types Clean Continental, Polluted Continental and Smoke. For instance Omar et al. (2009) underline that the two aerosol types Polluted Continental and Smoke are both slightly absorbing fine aerosols that are only differentiated by their altitude, The Clean Continental aerosol type should also include fine secondary sulfate and organic particles from natural origin, but has a significant supermicronic mode. For this reason we combine the two Polluted Continental and Smoke average vertical profiles, by doing a weighted average profile using their respective frequency, added in Fig. 9a. We assume that this weighted average combined vertical profile is adapted to the three OR, BC and SU aerosol species.
CALIOP measurements show that marine and polluted continental aerosols are confined in the boundary layer under $1000 \mathrm{~m}$, with respective maxima at 200 and $400 \mathrm{~m}$. Clean continental, smoke, dust and polluted dust aerosols are lifted to higher altitudes with maxima at 1000, 1300, 1200 and $1000 \mathrm{~m}$, respectively. These sharp gradients near surface are in agreement with airborne lidar profiles (Dulac and Chazette, 2003).

The dust vertical profile is similar in observations and both model simulations, as far as the vertical spread, which is the largest of all aerosols, is concerned. The major part of dust AOD (90\%) is situated between the surface and $4700 \mathrm{~m}$ for CALIOP (4000 m for MACC and $5000 \mathrm{~m}$ for RegCM4), which is coherent with previous studies (Hamonou et al., 1999; Mona et al., 2006; Kalivitis et al., 2007). However, the peak of dust AOD is higher in RegCM-4 (2600 m) than CALIOP $(1200 \mathrm{~m})$, and MACC has its maximum at surface and a local maximum at $900 \mathrm{~m}$. Sea-salt (maximum at $900 \mathrm{~m}$ ) and sulfate $(1900 \mathrm{~m})$ aerosols are also higher in RegCM-4 than in MACC (resp. at surface and $300 \mathrm{~m}$ ) and CALIOP, compared respectively to marine and polluted continental aerosols. On the contrary, black carbon aerosols are lower in MACC where maximum is at surface compared to RegCM$4(1400 \mathrm{~m})$ and CALIOP smoke $(1300 \mathrm{~m})$ and polluted continental $(400 \mathrm{~m})$. As a result, several differences have been shown between CALIOP and both models, so that we choose to keep CALIOP profiles for our reconstruction: marine (for $\mathrm{SS}$ ), dust (for SD) and the combination of polluted continental and smoke (for OR, BC and SU). The question is to know to which spatial and temporal variability these profiles can be included in the final product.

The aerosol vertical distribution is submitted to a strong seasonal and spatial variability, respectively, illustrated in Figs. 10 and 11. Figure 10 presents our three mean aerosol profiles (dust, sea-salt and the combined profile) over the Mediterranean basin for each of the four seasons, while Fig. 11 shows averages over our three regions: Southern Europe (a), the Mediterranean Sea (b) and Northern Africa (c). The main seasonal variability is linked to dust aerosols which are present in higher altitudes in spring and summer. This result is in agreement with Lidar measurements obtained in Central Mediterranean (Iorio et al., 2009). The polluted continental and smoke aerosols (combined profile) also peak at higher altitudes in summer. Differences between regions can also be noticed, with for instance highest anthropogenic aerosols (combined profile) over southern Europe than over Northern Africa (Fig. 11). Over the sea, dust aerosols can remain near the surface contrary to continental regions.

As a consequence, it is useful to take into account seasonal and geographical variability in our reconstruction with CALIOP data. In order to have vertical profiles representing the different aerosol types and regions, we resort to monthly means over different regions of the Mediterranean basin defined in Fig. 1 and Table 4. This allows to have enough CALIOP retrievals to calculate a significant mean, so that 

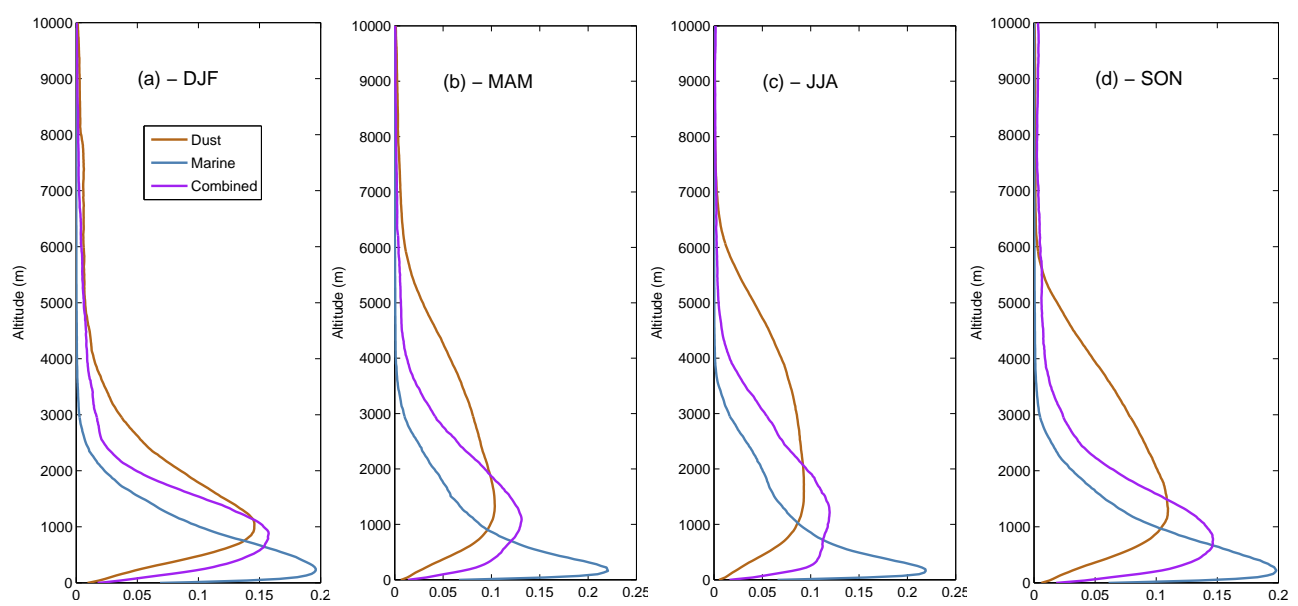

Fig. 10. Mean aerosol type vertical profile from CALIOP (2006-2010) over the Mediterranean basin for winter (DJF), spring (MAM), summer (JJA) and autumn (SON).
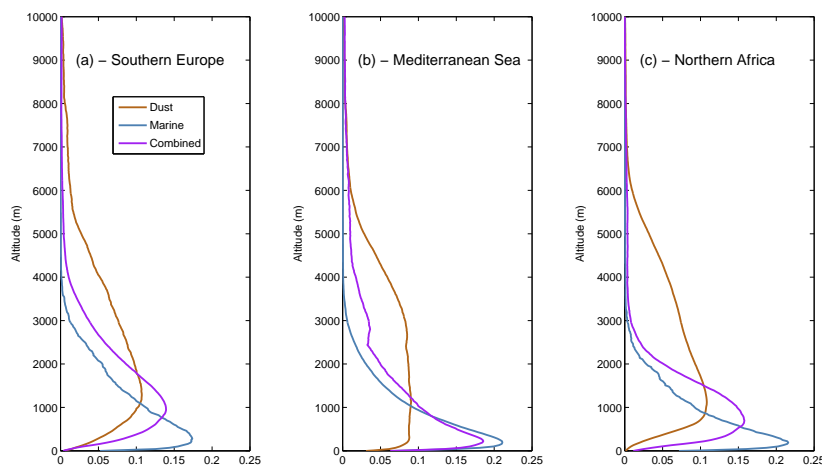

Fig. 11. Mean aerosol type vertical profile from CALIOP (20062010) over Southern Europe (left, region $8+9$ ), the Mediterranean sea (middle, region 5+6) and Northern Africa (right, region 1+2).

regions cannot be too small. Regions proposed in Fig. 1 take into account climatic and geographical characteristics of the Mediterranean basin. In particular, sea and land surfaces are separated. For each region, all the data from CALIOP between 2006 and 2010 have been gathered, in order to get these monthly averages for each aerosol type. Only the vertical shape from CALIOP has been used, to distribute the AOD from the bidimensional reconstruction product. Given the uncertainties in CALIOP data, the vertical resolution for our final product is based on the 60 MACC vertical levels. As the retrieval period of time is still short (only 2006-2010), the interannual variability in vertical distribution is not taken into account.

\subsection{Before the 2000s}

This comparison of AOD products and selection for a possible reconstruction can easily be achieved from 2000 when satellite retrievals are numerous. However, estimating AOD
Table 4. Regions of the Mediterranean basin for applying CALIOP AOD vertical profiles. Limits between regions are also indicated ( $\mathrm{AO}=$ Atlantic Ocean, $\mathrm{MS}=$ Mediterranean Sea, $\mathrm{RS}=\mathrm{Red}$ Sea, $\mathrm{BS}=$ Black Sea, NS = Northern Sea).

\begin{tabular}{lrl}
\hline CALIOP region & $\mathrm{N}^{\circ}$ & Limits \\
\hline Maghreb & 1 & $\mathrm{AO}, \mathrm{MS}$ and $11^{\circ} \mathrm{E}$ \\
Libya-Egypt & 2 & $11^{\circ} \mathrm{E}, \mathrm{MS}$ and RS \\
Red Sea & 3 & $\mathrm{RS}$ \\
Near-East & 4 & $\mathrm{RS}, \mathrm{MS}, \mathrm{BS}$ and $42^{\circ} \mathrm{N}$ \\
Western Sea & 5 & $\mathrm{MS}$ to the west of Italy \\
Eastern Sea & 6 & $\mathrm{MS}$ to the east of Italy \\
Black Sea & 7 & $\mathrm{BS}$ \\
Southeastern Europe & 8 & $13^{\circ} \mathrm{E}, 48^{\circ} \mathrm{N}, 30^{\circ} \mathrm{E}, \mathrm{BS}$ and $\mathrm{MS}$ \\
Southwestern Europe & 9 & $\mathrm{AO}, 48^{\circ} \mathrm{N}, 13^{\circ} \mathrm{E}$, and MS \\
Northern Europe & 10 & $\mathrm{AO}, \mathrm{NS}, 30^{\circ} \mathrm{E}$, and $48^{\circ} \mathrm{N}$ \\
Eastern Europe & 11 & $30^{\circ} \mathrm{E}, 42^{\circ} \mathrm{N}$ and $\mathrm{BS}$ \\
Scandinavia & 12 & $\mathrm{NS}$ and $30^{\circ} \mathrm{E}$ \\
British Isles & 13 & $\mathrm{AO}$ and $\mathrm{NS}$ \\
Northern Sea & 14 & $\mathrm{NS}$ \\
Northern Atlantic & 15 & $\mathrm{AO}, 44^{\circ} \mathrm{N}$ and $5^{\circ} \mathrm{W}$ \\
Atlantic & 16 & $\mathrm{AO}$ and $44^{\circ} \mathrm{N}$ \\
\hline
\end{tabular}

before the 2000s is a much more complex problem as only few sensors are available and their spatial coverage and quality are not as good. Figure 12 presents the averaged AOD map over the Mediterranean basin over the 1980s for the available satellite data as well as the simulation from LMDzOR-INCA and the multi-model ACCMIP mean. AVHRR, LMDz-OR-INCA and ACCMIP are in quite good agreement over the sea with stronger AOD than in the present conditions. The averaged AOD over the Mediterranean Sea during this period is 0.245 for AVHRR, 0.28 for LMDz-OR-INCA and 0.29 for ACCMIP. LMDz-OR-INCA and ACCMIP also clearly show a maximum AOD in Europe reaching 0.315 and 0.318 , respectively, on average over the European continent 
(up to 0.45 in Central Europe for LMDz-OR-INCA), which is also much higher than in present conditions (see Table3). This maximum could not be verified using available satellite data for this period due to the absence of AOD retrievals over continental surfaces at that time. However, it could be related to important sulfate emissions in the 1980s, which is a well-known phenomenon (e.g. Pinker et al., 2005; Vautard et al., 2009; Wild, 2009). As in present conditions, LMDzOR-INCA AOD over Northern Africa is higher than all the other products available over this region, while ACCMIP AOD over this region is similar to the 2000s.

The other datasets (MVIRI, TOMS and CZCS) have lower AOD over the sea. For CZCS, whose algorithm is close to SeaWiFS, this is probably due to the rejections of high AOD retrievals, thus, explaining a very low AOD over the Mediterranean Sea ( 0.147 on average). MVIRI and TOMS AOD over the sea (resp. 0.144 and 0.121 ) are also low compared to other datasets. TOMS AOD over Africa (0.231) is yet closer to MODIS and MISR retrievals in present conditions.

Figure 13 presents the annual AOD average between 1979 and 2010 over Europe (a), the Mediterranean Sea (b) and Northern Africa (c) for all satellite and model datasets. This figure highlights the AOD underestimation of CZCS, TOMS and MVIRI in the 1980s, and MERIS and SeaWiFS later, which are far from the other datasets over the sea (Fig. 13b). This is also visible for the overestimation of MERIS over the European continent (Fig. 13a). However AVHRR and LMDz-OR-INCA present the same decrease in AOD from the early 1980s likely due to the decrease in European sulfate emissions. The high AOD value obtained in 1992 visible in MVIRI, AVHRR and TOMS is probably linked to the volcanic eruption of Pinatubo: Moulin et al. (1997b) estimate a possible bias as high as +0.04 for summer 1992 . More generally, caution must be used with long aerosol time series such as retrieved from AVHRR and MVIRI, as the sensors have been used on different platforms during the period. Breaks in the time series can be linked to problems in cross-calibration (Moulin et al., 1996). Figure 14 illustrates the issue for MVIRI data. It shows the difference in monthly mean AOD from June 1983 to December 1997, compared to the monthly average on the whole period. Changes in satellite clearly coincide with discontinuities, despite the great care put in the successive MVIRI sensors calibration (Moulin et al., 1996). It turns out that the low sensitivity of the MVIRI sensor (only 64 numerical counts for Meteosat-2 and 3, and 255 for Meteosat-4 and 5) produced relatively large uncertainties in radiance measurements and, therefore, in crosscalibration of the different sensors. As far as AVHRR is concerned, Shindell et al. (2013a) have shown that the trends for water areas near Europe are fairly consistent across different analyses of AVHRR data (contrary to Asia notably).
Given the small number of reliable AOD measurements over the whole 1979-2009 period, we resort to using model data from the ACCMIP intercomparison exercise. Table 5 presents the sulfate AOD differences between the timeslices 2000 and 1980 for each ACCMIP model. The decrease in sulfate AOD ranges from -0.05 to -0.19 over Europe, and from -0.03 to -0.08 over the Mediterranean Sea. LMDzOR-INCA is a median model, showing sulfate trends close to the ACCMIP mean. It should also be noted that no significant trend has been noticed for BC and OR aerosols over Europe and the Mediterranean Sea (the ACCMIP mean trend is -0.00 for $\mathrm{BC}$ and $\mathrm{OR}$ ).

To sum up, Figs. 12 and 13 show a strong dispersion between the different products in AOD before the 2000s. The main phenomenon is the decrease in atmospheric aerosol content between 1979 and 2000 caused by reduction in sulfate emissions already mentioned. Although this dispersion in AOD makes it difficult to assess the LMDz-OR-INCA and ACCMIP datasets, their AOD is close to the AVHRR retrieval over the Mediterranean Sea. Moreover, results given by the ACCMIP exercise have proved LMDz-OR-INCA was a median model considering these trends. The solution for our reconstruction could be to keep only the trend in sulfate AOD in the LMDz-OR-INCA model between 1979 and 2000. Indeed, the chronology of the interannual variability in this model is fictitious, but not the trend, which is controlled by reference sulfur emissions. From this trend, we can build the sulfate AOD field from our climatology established with MODIS and MACC. As the other aerosols are not affected by decadal trends (figure not shown), we can apply monthly climatologies coming from the recent past decade.

\section{Reconstruction of the aerosol field}

\subsection{Building a 4-D-blended product}

This section presents the reconstruction resulting from the comparison of Sect. 3. As mentioned in Sect. 3, the lack of data before 2000 leads us to separate two periods. With the chosen products, namely RegCM-4, MACC and AQUA/MODIS, the common period of time is 20032009. Over this period, we propose a 4-D-blended product composed of monthly AOD climatologies combined with CALIOP profiles for the vertical dimension. This product has been achieved at a $50 \mathrm{~km}$ resolution (after a linear interpolation for MODIS and MACC) over the domain shown in Fig. 1, with a Lambert conformal projection (origin point: $43^{\circ} \mathrm{N}, 15^{\circ} \mathrm{W}$ ). It must be noted that the choice of the domain is not essential, and a similar work to a larger domain could be easily carried out.

Total AOD field is given by AQUA/MODIS, whereas MACC (for sulfates, black and organic carbon) and RegCM4 (for dust and sea-salt) provide the separation into five aerosol species. For each month of the period 2003-2009, 


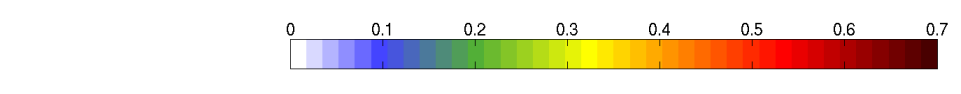

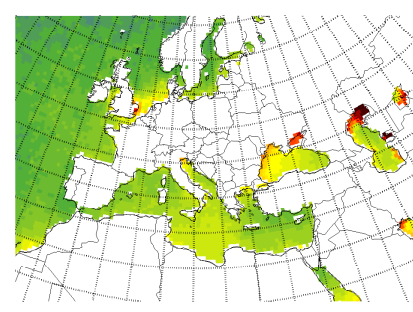

(a) - NOAA/AVHRR (1982-1990)

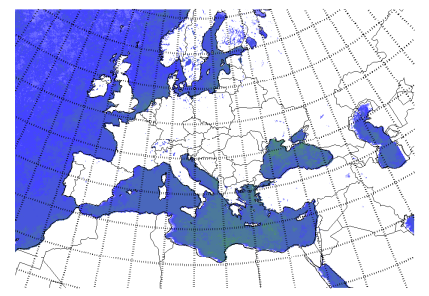

(d) - NIMBUS7/CZCS (1979-1985)

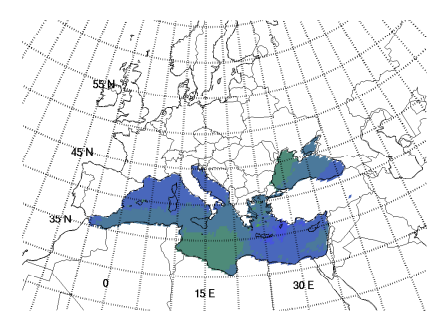

(b) - Meteosat/MVIRI (1984-1990)

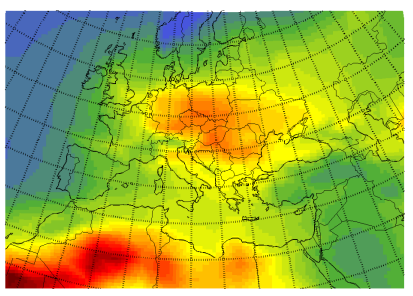

(e) - LMDz-OR-INCA (1980-1990)

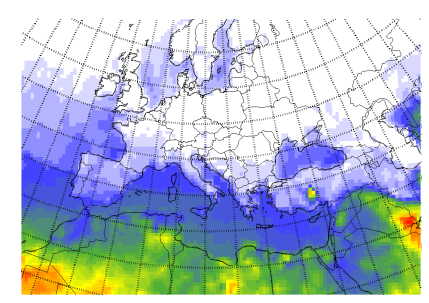

(c) - NIMBUS7/TOMS (1980-1990)

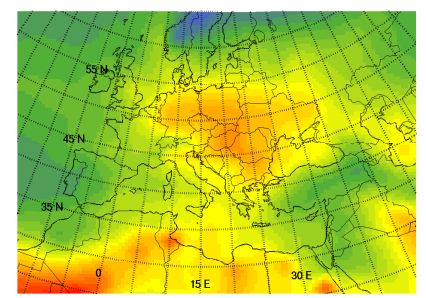

(f) - ACCMIP (1980)

Fig. 12. Mean Aerosol Optical Depth (AOD) at $550 \mathrm{~nm}$ from different products over the Mediterranean basin between 1979 and 1990 .

Table 5. AOD differences between 2000 and 1980 in the ACCMIP models.

\begin{tabular}{cccccccccc}
\hline Region & CICERO & GFDL & GISS & GISS-TOMAS & HadGEM2 & LMDz-OR-INCA & NCAR-3.5 & NCAR-5.1 & Mean \\
\hline Europe & -0.14 & -0.14 & -0.19 & -0.05 & -0.10 & -0.12 & -0.10 & -0.05 & -0.11 \\
Mediterranean Sea & -0.06 & -0.08 & -0.06 & -0.03 & -0.05 & -0.05 & -0.05 & -0.03 & -0.05 \\
\hline
\end{tabular}

the raw AOD coming from the model is normalised by the total AOD from MODIS. This normalisation is applied to each month individually so that total AOD of the reconstruction is identical to AQUA/MODIS for every month. The following equations summarise the method:

$\mathrm{AOD}_{\text {rec }}($ aer,lon,lat,y,m) $=$
$\mathrm{AOD}_{\text {model }}(\mathrm{aer}, \mathrm{lon}, \mathrm{lat}, \mathrm{y}, \mathrm{m}) \times C($ lon,lat,y,m)

with the normalisation coefficient:

$C($ lon,lat,y,m $)=\frac{\operatorname{AOD}_{\text {MODIS }}(\text { lon,lat,y,m) }}{\sum_{\text {aer }} \operatorname{AOD}_{\text {model }}(\text { aer,lon,lat,y,m) }}$

where aer is one aerosol among the five types, rec is the new reconstruction, model is either MACC (for sulfates, black and organic carbon) or RegCM-4 (for sea-salt and dust), and lon, lat, y and $\mathrm{m}$, respectively, stand for longitude, latitude, year and month.

This method gives three-dimensional AOD fields (longitude, latitude and time), and the vertical dimension can be added with CALIOP data. The AOD is vertically distributed according to monthly profiles of the corresponding region. Figure 15 presents the AOD averages over 2003-2009 for each aerosol type.

Over the 1979-2003 period, the AOD fields for desert dust, sea-salt, black and organic carbon aerosols are given by the multi-year monthly means of the reconstruction between
2003 and 2009. Given the conclusions of Sect. 3, we assume there is no significative change in AOD for these species. On the contrary, sulfate aerosols are submitted to a decreasing trend, which is reproduced in our reconstruction according to the following equation:

$$
\begin{aligned}
& \mathrm{AOD}_{\mathrm{rec}}(\mathrm{SU}, \text { lon,lat,y,m })= \\
& \mathrm{AOD}_{\mathrm{INCA}}(\mathrm{SU}, \text { lon,lat,y,m }) \times \frac{\mathrm{AODM}_{\mathrm{rec}}(\mathrm{SU}, \mathrm{lon}, \mathrm{lat}, \mathrm{m})}{\mathrm{AODM}_{\mathrm{INCA}}(\mathrm{SU}, \text { lon,lat }, \mathrm{m})}
\end{aligned}
$$

where SU stands for sulfate aerosols, AODM represents the average over the period 2003-2009 for the reconstruction $(\mathrm{rec})$ or the LMDz-OR-INCA model, with y the year between 1979 and 2002. AOD INCA is the AOD from the LMDz-ORINCA model given with eleven-year moving averages. As a result, contrary to the 2003-2009 period, there is no year to year variability in the reconstruction between 1979 and 2003, but only a decreasing trend for sulfate aerosols.

\subsection{Characteristics of the new climatology}

AOD averages maps over the period 2003-2009 for each aerosol type can be seen in Fig. 15. As shown in Sect. 3.3, soil dust and sulfate aerosols are prevailing over the Mediterranean basin. In terms of seasonal cycle, the main patterns mentioned in Sect. 3.2 are present in the reconstruction. Figure 16a presents the monthly AOD average over the period 2003-2009 for each aerosol type. The dust maximum occurs 


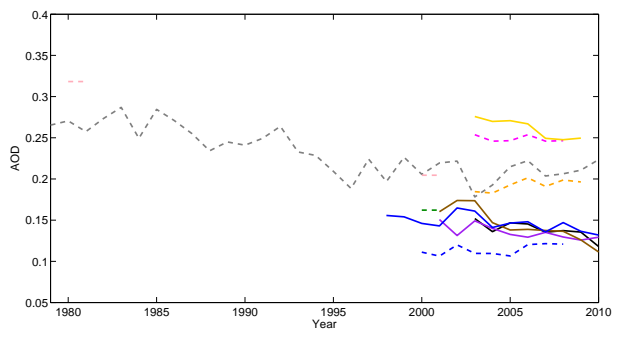

(a) - Europe
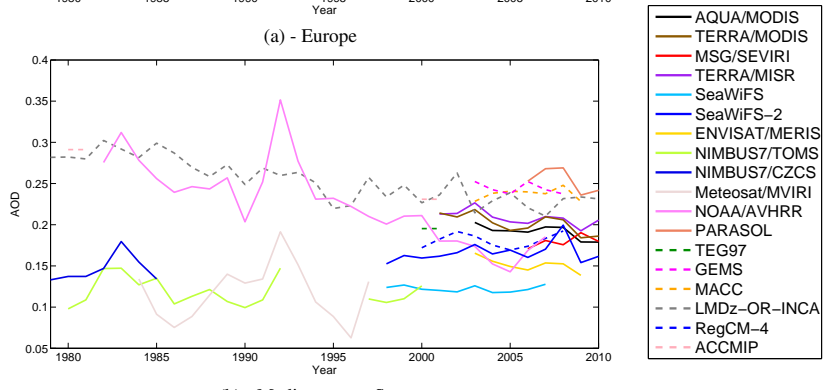

(b) - Mediterranean Sea

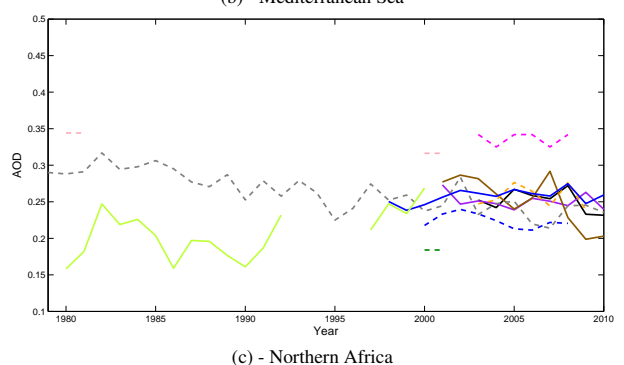

(c) - Northern Africa

Fig. 13. AOD annual averages for each dataset (satellites and models) over the European continent (region $8+9+10$, top), the Mediterranean Sea (region 5 +6 , middle) and Northern Africa (region $1+2$, bottom) between 1979 and 2010 .

in spring and summer over Northern Africa with a monthly peak at 0.33 in June. Over the European continent, sulfate aerosols are prevailing, especially in spring and summer. Other aerosols have less influence, but the maximum of organic carbon in summer and sea-salt aerosols in winter can be noticed. Total AOD seasonal cycle is obviously the same as AQUA/MODIS.

Figure $16 \mathrm{~b}$ presents the annual averages for the different aerosol types and total AOD. The interannual variability is generally low between 2003 and 2009 with a standard deviation for total AOD over the sea equal to 0.008. However, a slight decrease in dust and sulfate AOD can be noticed. For dust aerosols, this trend is -0.0045 per year over Northern Africa and is statistically significant at the 0.05 level (Student's test). For sulfate aerosols the trend is not significant even if it reaches -0.0017 per year over Europe. Total AOD decreases by 0.0023 per year over the Mediterranean Sea (not significant at the 0.05 level). This AOD decrease has already been shown in previous studies for total AOD over the Mediterranean basin (Papadimas et al., 2009).

Our blended product also enables to identify months affected by exceptional AOD loads, notably because of unusual

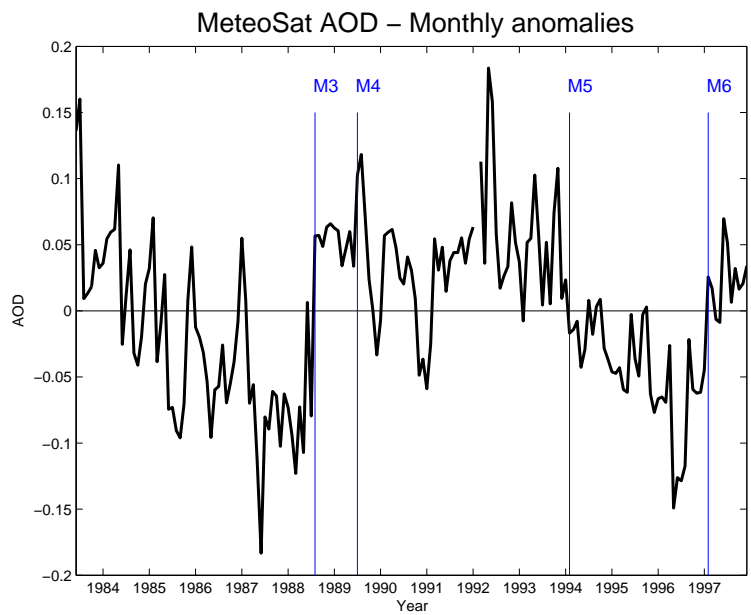

Fig. 14. Monthly AOD anomalies over the Mediterranean Sea retrieved by MVIRI sensors onboard Meteosat-2 to -6 . Blue lines indicate platform changes.

weak or intense dust and sulfate aerosol contents. Figure 17 presents the anomalies of monthly AOD averages over the Mediterranean Sea, namely for every month the difference between the AOD of this month and the multi-year monthly average (for every aerosol type and total AOD). For example, May 2003 and February 2008 were characterised by lower dust aerosol loads whereas June 2006 and March 2009 have been submitted to a very strong dust AOD.

With regards to the longer period (1979-2009), Fig. 16c presents the annual AOD average over the Mediterranean Sea for each aerosol type and total AOD. The decrease between 1979 and 2009 is controlled by sulfate aerosols. The trend, equal to -0.051 per decade for sulfate AOD over the European continent, is coherent with the one in Zubler et al. (2011b) in the COSMO regional climate model. Over the sea, the decrease for sulfate AOD is -0.023 per decade. The total AOD trend is also in good agreement with long-term groundbased measurements in Germany (Ruckstuhl et al., 2008). In this study, the trend per decade between 1986 and 2005 in Zingst and Lindenberg was respectively -0.106 and -0.119 , against -0.074 and -0.097 for the reconstruction.

\subsection{Discussion}

This comparison of different aerosol products has led to a reconstruction of a new monthly aerosol climatology, that could be very useful to several RCMs for aerosol-climate studies over the Mediterranean. However, it should be kept in mind that even if our product has been built to give the most relevant estimation of AOD, it can present some drawbacks. For example, the retrieved AOD over the Near East differs a lot from sensor to sensor, and MODIS may not be the most relevant sensor in this particular region (from the evaluation with AERONET measurements, Sect. 3.1). More generally, our evaluation suffers from the lack of AERONET 


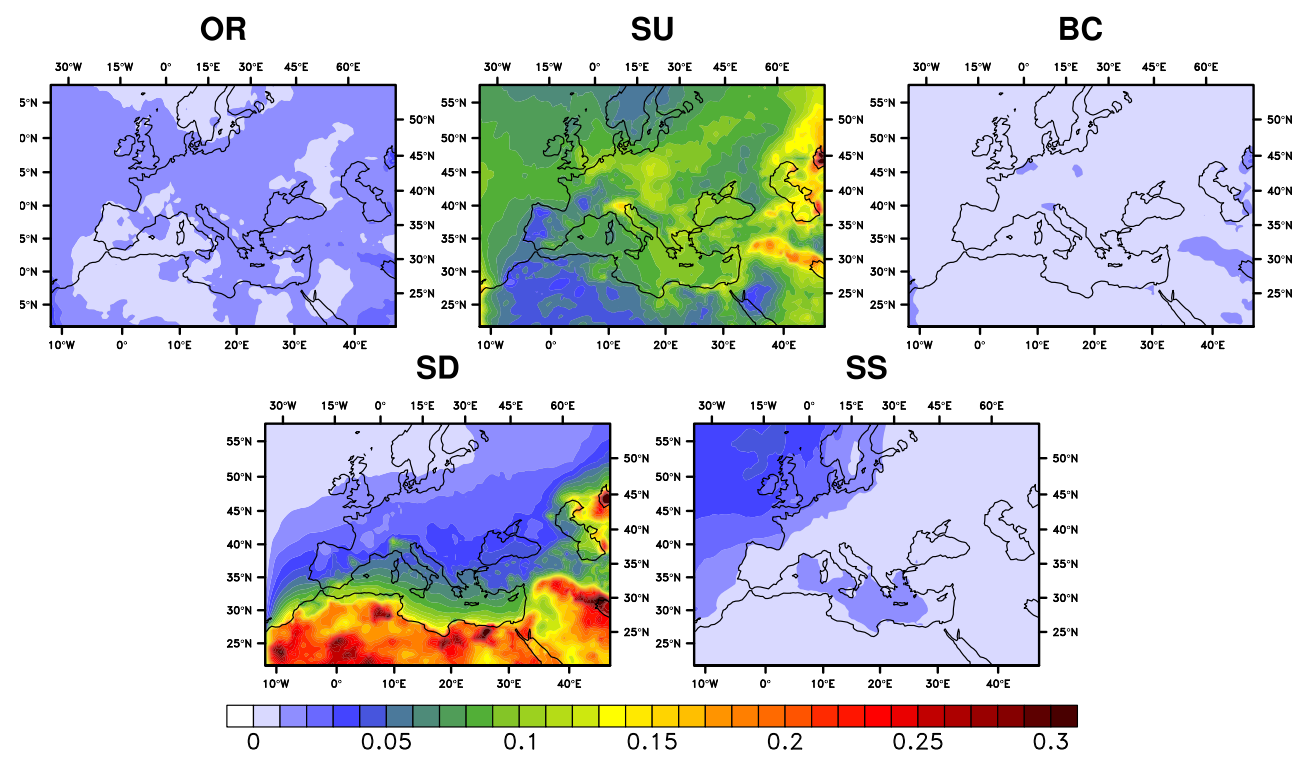

Fig. 15. Average aerosol optical depth of the reconstruction product over the period 2003-2009 for each aerosol type $(\mathrm{OR}=$ organic carbon, $\mathrm{SU}=$ sulfates, $\mathrm{BC}=$ black carbon, $\mathrm{SD}=$ soil dust, $\mathrm{SS}=$ sea salt $)$.

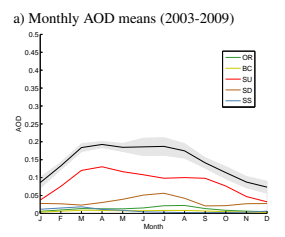

b) Annual AOD means (2003-2009)
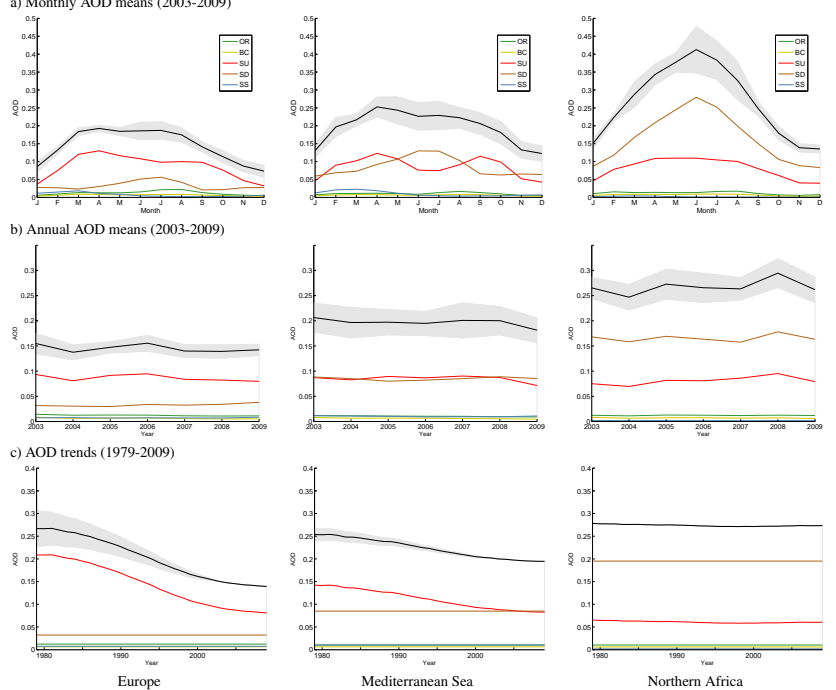

Fig. 16. Seasonal (a) and annual (b and c) AOD averages in the reconstruction field over Europe (left, region $8+9+10$ ), the Mediterranean Sea (middle, region $5+6$ ) and Northern Africa (right, region $1+2$ ) for the five aerosol species (in colour) and total AOD (in black). Top (a) and middle (b) plots concern the 2003-2009 period, bottom plots (c) the 1979-2009 period. The confidence interval at the level 0.05 is indicated in gray.

stations over Northern Africa and over the sea. Given these uncertainties, the final reconstruction is provided with an estimation of error based on the four satellite products covering the whole domain (AQUA/MODIS, TERRA/MODIS, TERRA/MISR and SeaWiFS-2). Figure 18 (top) presents the standard deviation of the ensemble of these four datasets.

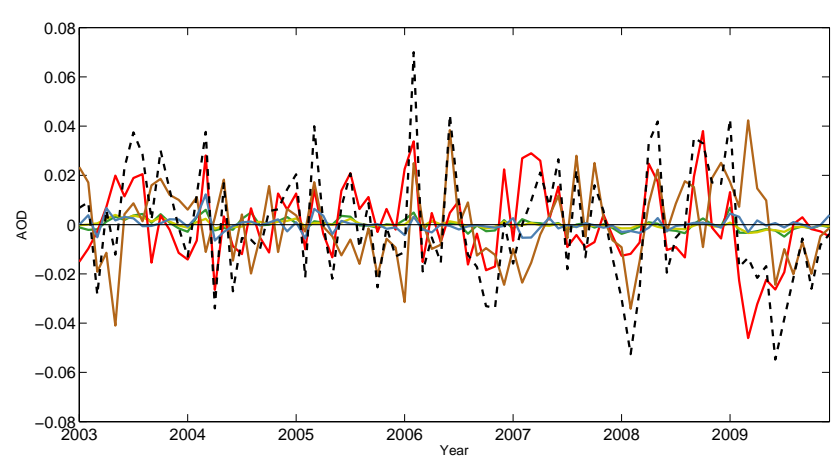

Fig. 17. AOD monthly anomalies from the reconstruction product over the period 2003-2009 for every aerosol type (red=SU, blue $=\mathrm{SS}$, yellow $=\mathrm{BC}$, green $=\mathrm{OR}$ and brown $=\mathrm{SD}$ ) and for total AOD (dashed black line) over the Mediterranean Sea.

Uncertainties are high over Near-East and northern Africa, whereas they are lower over Europe. From this standard deviation, a confidence interval at the level 0.05 has been calculated, and added (in gray) in Fig. 16 for monthly and annual averages over the three regions for the 2003-2009 periods. A similar confidence interval has also been calculated for the 1979-2009 period, based on the standard deviation between the different ACCMIP models.

No means has been found to evaluate properly the separation between the different aerosol types. Previous studies (Lee and Adams, 2010; Shindell et al., 2013a) have determined the dominant mass type in different locations around the world, which is more difficult in this regional study (except for dust over the Sahara desert) as the Mediterranean area is affected by mixtures of different aerosols. The 

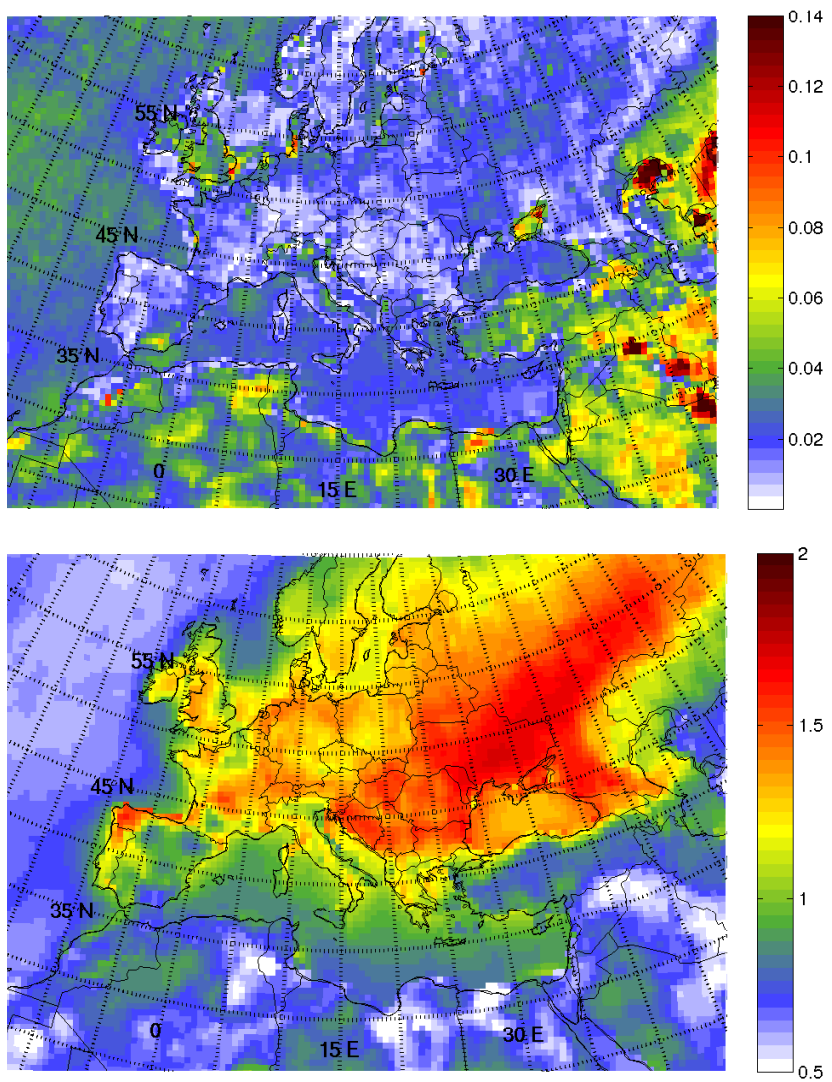

Fig. 18. Standard deviation of total $A O D$ at $550 \mathrm{~nm}$ (top) and Angstrom exponent (AQUA/MODIS, bottom) over the Mediterranean region for the 2003-2009 period.

separation between fine and coarse mode available for example in the MODIS dataset (Remer et al., 2005) could be used considering fine aerosols are essentially sulfates, BC and organic aerosols. However, the fine fraction of dust aerosols would not be taken into account in this case. Moreover, uncertainties are still important in this kind of product ( $\mathrm{Yu}$ et al., 2009), showing no consensus on an observationallyconstrained anthropogenic AOD. The same problem is raised for the absorption aerosol optical depth (AAOD), which could be estimated with the black carbon and dust aerosols. Dust aerosols are, however, more or less absorbing depending notably on their size and hematite content. Some organic aerosols are not exclusively scattering (Mallet et al., 2013). As a result, the method used in the present work has been to evaluate and compare the total AOD data from each model, highlighting the limitations for some components (e.g., sulfates in RegCM-4, dust aerosols in MACC). The final reconstruction is a first attempt to have an AOD climatology over the Mediterranean basin, that has none of the mentioned limitations.

Besides this comparison has been carried out for only one wavelength $(550 \mathrm{~nm})$. As mentioned in Sect. 2.1, the Angstrom exponent enables to have AOD spectral varia- tions following Eq. (1). The average angstrom exponent retrieved by AQUA/MODIS over the 2003-2009 period is consequently provided in Fig. 18 (bottom). This parameter is derived from variation of AOD between 470 and $660 \mathrm{~nm}$ over land (including bright surfaces with the deep blue algorithm) and between 550 and $865 \mathrm{~nm}$ over the sea. Northern Africa is affected by low values (between 0.5 and 0.8 ), revealing the presence of dust aerosols. On the contrary, anthropogenic aerosols over Eastern Europe give an Angstrom exponent higher than 1.5. Not all climate models can take into account this information, depending on the spectral bands of their radiative schemes (Randles et al., 2013).

Another point to mention is the consideration of the other aerosol species. Secondary organic aerosols and ammonium nitrates are notably missing in this comparison, which is also the case in most of climate models (Shindell et al., 2013a). Only 2 models in the ACCMIP exercise include nitrate aerosols, and nitrate does not seem to be abundant over the Mediterranean compared to sulfates (Sciare et al., 2008). Nitrates, which could have a potential impact on global climate in future (Bellouin et al., 2011), and other aerosol types, could be included in the next comparative exercises when most models include them.

As far as volcanic aerosols are concerned, they also play an important role in radiation-climate interactions (Robock, 2000), but this study has focused on the main different tropospheric aerosols. We would advise the use of a historical dataset of volcanic eruptions to take into account the related stratospheric aerosols, which are not included in our new climatology. For example, the aerosols diagnosed from Amman et al. (2007) are a relevant choice, providing the zonal mean AOD of stratospheric aerosols. Over our period of time, two volcanic eruptions affect the Mediterranean region: El Chichon in March 1982 and Mount Pinatubo in November 1991. The emitted aerosols remain during several months in the stratosphere over the Mediterranean (Chazette et al., 1995).

Finally, it should be stressed that our monthly average AOD distribution accounts for the high spatial variability in the tropospheric aerosol load, but does not account for its even higher daily variability.

\subsection{Aerosol optical properties}

Another source of uncertainty when applying this reconstruction in RCMs concerns the aerosol optical properties. Wang et al. (2006) have shown the impact of dust optical properties on radiative forcing. They underline the importance of the accuracy of optical properties to estimate radiative forcing and consequences on climate. Solmon et al. (2008) have underlined the importance of the dust single scattering albedo on the hydrological response of the RegCM model over Western Africa. In RCMs which do not have interactive aerosol schemes, these optical properties have to be determined accurately. For that reason, we propose in Table 6 values for single scattering albedo (SSA) and asymmetry parameter $(g)$. 
Table 6. Aerosol optical properties obtained from Mie calculations for different aerosol types at $550 \mathrm{~nm}$ (first line for each aerosol) and $1 \mu \mathrm{m}$ (second line) wavelengths. Values between square brackets correspond to an uncertainty range of $10 \%$ on the effective radius. SSA $=$ Single Scattering Albedo, $g=$ asymmetry factor. These properties are provided in dry state. Changes on optical properties should be made depending on the relative humidity (Mallet et al., 2003).

\begin{tabular}{|c|c|c|c|c|c|c|c|}
\hline \multirow[b]{2}{*}{ Aerosol } & \multirow{2}{*}{$\begin{array}{l}\text { Effective } \\
\text { radius } \\
(\mu \mathrm{m})\end{array}$} & \multirow{2}{*}{$\begin{array}{c}\text { Standard } \\
\text { deviation } \\
\quad(\mu \mathrm{m})\end{array}$} & \multirow{2}{*}{$\begin{array}{c}\text { Refractive } \\
\text { index }(\mu \mathrm{m}) \\
550 \mathrm{~nm} 1 \mu \mathrm{m}\end{array}$} & \multicolumn{2}{|c|}{ SSA } & \multicolumn{2}{|c|}{$g$} \\
\hline & & & & $550 \mathrm{~nm}$ & $1 \mu \mathrm{m}$ & $550 \mathrm{~nm}$ & $1 \mu \mathrm{m}$ \\
\hline SS & $\begin{array}{c}0.35 \\
{\left[\begin{array}{ll}0.32 & 0.38\end{array}\right]}\end{array}$ & 1.75 & $\begin{array}{c}1.45-0.000031 \mathrm{i} \\
1.45-0.00006 \mathrm{i}\end{array}$ & $\begin{array}{c}0.99 \\
{[0.990 .99]}\end{array}$ & $\begin{array}{c}0.99 \\
{\left[\begin{array}{ll}0.99 & 0.99\end{array}\right]}\end{array}$ & $\begin{array}{c}0.72 \\
{\left[\begin{array}{ll}0.71 & 0.72\end{array}\right]}\end{array}$ & $\begin{array}{c}0.73 \\
{\left[\begin{array}{ll}0.73 & 0.73\end{array}\right]}\end{array}$ \\
\hline SD & $\begin{array}{c}0.036 \\
{[0.0320 .040]} \\
0.36 \\
{[0.320 .40]}\end{array}$ & 1.97 & $1.51-0.008 \mathrm{i}$ & 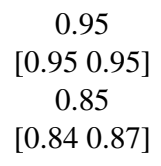 & $\begin{array}{c}0.93 \\
{\left[\begin{array}{ll}0.92 & 0.93\end{array}\right]} \\
0.91 \\
{[0.900 .92]}\end{array}$ & $\begin{array}{c}\quad 0.62 \\
{\left[\begin{array}{ll}0.60 & 0.63\end{array}\right]} \\
0.74 \\
{\left[\begin{array}{ll}0.73 & 0.75\end{array}\right]}\end{array}$ & $\begin{array}{c}0.52 \\
{\left[\begin{array}{ll}0.49 & 0.54\end{array}\right]} \\
0.72 \\
{\left[\begin{array}{ll}0.71 & 0.72\end{array}\right]}\end{array}$ \\
\hline OR & $\begin{array}{c}0.027 \\
{[0.0240 .030]} \\
0.29 \\
{[0.260 .32]}\end{array}$ & 1.95 & $1.45-0.001 \mathrm{i}$ & $\begin{array}{c}0.99 \\
{[0.990 .99]} \\
0.98 \\
{[0.980 .98]}\end{array}$ & $\begin{array}{c}0.98 \\
{[0.970 .98]} \\
0.99 \\
{[0.990 .99]}\end{array}$ & $\begin{array}{c}0.52 \\
{\left[\begin{array}{ll}0.49 & 0.54\end{array}\right]} \\
0.73 \\
{\left[\begin{array}{ll}0.73 & 0.73\end{array}\right]}\end{array}$ & $\begin{array}{c}0.35 \\
{\left[\begin{array}{ll}0.32 & 0.38\end{array}\right]} \\
0.71 \\
{\left[\begin{array}{ll}0.71 & 0.71\end{array}\right]}\end{array}$ \\
\hline $\mathrm{BC}$ & $\begin{array}{c}0.028 \\
{[0.0250 .031]}\end{array}$ & 1.94 & $\begin{array}{l}1.83-0.74 \mathrm{i} \\
1.91-0.68 \mathrm{i}\end{array}$ & $\begin{array}{c}0.32 \\
{\left[\begin{array}{ll}0.30 & 0.33\end{array}\right]}\end{array}$ & $\begin{array}{c}0.24 \\
{\left[\begin{array}{ll}0.22 & 0.26\end{array}\right]}\end{array}$ & $\begin{array}{c}0.43 \\
{\left[\begin{array}{lll}0.40 & 0.45]\end{array}\right]}\end{array}$ & $\begin{array}{c}0.31 \\
{[0.290 .33]}\end{array}$ \\
\hline SU & $\begin{array}{c}0.040 \\
{[0.0360 .044]}\end{array}$ & 1.74 & $\begin{array}{l}1.52-0.0005 \mathrm{i} \\
1.51-0.0005 \mathrm{i}\end{array}$ & $\begin{array}{c}0.99 \\
{[0.990 .99]}\end{array}$ & $\begin{array}{c}0.99 \\
{[0.990 .99]}\end{array}$ & $\begin{array}{c}0.53 \\
{\left[\begin{array}{lll}0.50 & 0.55]\end{array}\right]}\end{array}$ & $\begin{array}{c}0.35 \\
{[0.320 .38]}\end{array}$ \\
\hline
\end{tabular}

These values come from calculations carried out with a Mie code from effective radius observed in the ESCOMPTE campaign (Mallet et al., 2003) and refractive indexes published by Krekov (1993). An uncertainty range of $10 \%$ has been taken into account for the effective radius: the associated values for SSA and $g$ are indicated between square brackets. All these parameters are provided in dry state. Fine and accumulation modes have been separated for dust and organic aerosols. These optical parameters are only provided as advised values for aerosol-climate studies over the Mediterranean region: a further comparison with all these optical parameters is beyond the scope of the paper.

They result from several published studies over the Mediterranean basin.

\section{Conclusions}

The present work includes an intercomparison of the main satellite-derived and model-simulated aerosol products over the Mediterranean basin and surrounding regions. Since 2000 many sensors have been launched to retrieve aerosols, but few data are available before. The comparison between the different products and also ground-based measurements from the AERONET network highlights the quality of AQUA/MODIS and TERRA/MODIS retrievals. Both show a relevant spatial and temporal aerosol variability. MISR AOD presents a similar spatial and temporal structure, but its scores against AERONET measurements are not as high as MODIS. These three products are the only satellitederived products to cover the whole domain, ocean and land included. Over the sea, AVHRR, SEVIRI and PARASOL have also relevant AOD retrievals to some extent, with a good temporal coverage for AVHRR (1982-2007). On the contrary, this study clearly shows the limitation of some datasets, either recent such as MERIS and SeaWiFS, or historical such as MVIRI, TOMS and CZCS. MERIS overestimates AOD over the European continent, whereas the others underestimated AOD over the sea.

Most model-based products are able to reproduce the spatiotemporal variability of AOD over the basin. The MACC reanalysis has proved to be the closest to AERONET measurements, but suffers from a lack of dust aerosols over Northern Africa. The RegCM-4 model results have the advantage to include a generation interactive scheme for dust and sea-salt aerosols at a high resolution. The LMDz-ORINCA model and the other ACCMIP models are able to reproduce the decreasing trend in total AOD (due to sulfate aerosols), observed notably in the only reliable satellite sensor over this period (AVHRR). LMDz-OR-INCA has been proved to be a median model among the ACCMIP models. With regards to the vertical dimension, MACC and RegCM4 show slight differences with CALIOP. CALIOP retrievals enable us to get three different aerosol vertical profiles for dust, sea-salt and submicronic components (organics, black carbon and sulfates) over various subregions. Dust aerosols show a larger vertical spread than the other aerosols such as 
marine and anthropogenic aerosols which are confined in the boundary layer with the exception of forest fire smoke.

This comparative synthesis leads to a first 4-D reconstruction of the monthly AOD field over the Mediterranean basin and surrounding regions over the 2003-2009 period, that could be used to force RCMs over this region. AQUA/MODIS data is chosen for total AOD, while the apportionment into five aerosol species is achieved with MACC for sulfates, black and organic carbon, and with RegCM-4 for dust and sea-salt aerosols. Our product also includes a vertical dimension based on CALIOP retrievals, which enables for example to take into account the higher altitudes of dust aerosols. The main patterns, notably dust loads over Northern Africa and sulfate aerosols over Europe, are reproduced in the reconstruction. Seasonal cycle shows a dust maximum in spring and summer. Interannual variability shows a slight decrease in dust and sulfate AOD. This blended product also enables us to identify exceptional months in terms of aerosol loads, such as June 2006 for dust aerosols.

Before 2003 the interannual aerosol variability is controlled by the decrease in sulfate aerosols. Our reconstruction is consequently extended to the period 1979-2003 by applying the trend from LMDz-OR-INCA model, based on the recent emission reconstruction proposed by Lamarque et al. (2010), and equal to -0.051 per decade over Europe. The other aerosol species are assumed to be constant given their low interannual variability. Their fields correspond to the multi-year monthly means of the initial reconstruction over 2003-2009. We finally get a complete 4-D AOD field for five aerosol species for the 1979-2009 period, over the whole domain at a $50 \mathrm{~km}$ resolution, ocean and continental surfaces included, which could be used in RCMs for aerosol-climate studies. This long reconstruction will also be possibly used to study the dimming-brightening phenomenon in the region. An AOD trend of -0.05 per decade could cause an increase in surface shortwave radiation by about $5 \mathrm{~W} \mathrm{~m}^{-2}$ per decade (Zubler et al., 2011b). The reconstruction will be tested in atmosphere RCMs and in coupled atmosphere-ocean RCMs (e.g., Somot et al., 2008) in the frame of the programmes MedCORDEX, ChArMEx and HyMeX, in order to investigate the impact of natural and anthropogenic aerosols on the Mediterranean climate and the Mediterranean Sea.

Acknowledgements. We would like to thank Meteo-France for the financial support of the first author. This work is part of the Med-CORDEX initiative (www.medcordex.eu) and a contribution to the HyMeX and ChArMEx programmes. This new AOD climatology is indeed available on the ChArMEx database (http://mistrals.sedoo.fr/ChArMEx). This research has received funding from the French National Research Agency (ANR) project ADRIMED (contract ANR-11-BS56-0006) and from the FP7 European Commission project CLIMRUN (contract FP7ENV-2010-265192). MODIS and MERIS data used in this paper were retrieved from the Giovanni online data system, developed and maintained by the NASA GES DISC. MISR and CALIOP data were obtained from the NASA Langley Research Center Atmospheric Science Data Center, SeaWiFS and CZCS data from the NASA Ocean Biology Processing Group, AVHRR data from the NOAA/National Climatic Data Center and TOMS data from the NASA/GSFC TOMS group. We also thank the ICARE Data and Services Center for providing access to the PARASOL and SEVIRI data used in this study, and Cyril Moulin for providing his historical MVIRI data. We thank the PI investigators of the different AERONET stations and their staff for establishing and maintaining all the sites used in this investigation. GEMS was funded by the European Commission between 2004 and 2009 as part of the 6th Framework Programme under contract number SIP4-CT-2004-516099, and MACC was funded between 2009 and 2011 as part of the 7th Framework Programme, pilot core GMES Atmospheric Service under contract number 218793. We thank all the people taking part in the ACCMIP project, notably other scientists involved in the development of models, namely Toshihiko Takemura and Kengo Sudo for MIROC-CHEM, Stig Dalsoren for CICERO-OsloCTM2, and Greg Faluvegi for GISSE2-R. The CESM project (which includes NCAR-CAM3.5 and NCAR-CAM5.1) is supported by the National Science Foundation and the Office of Science (BER) of the US Department of Energy. The National Center for Atmospheric Research is operated by the University Corporation for Atmospheric Research under sponsorship of the National Science Foundation.

Edited by: O. Dubovik

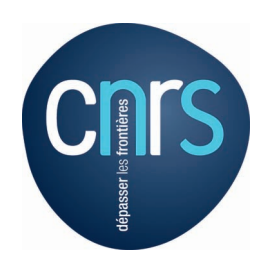

The publication of this article is financed by CNRS-INSU.

\section{References}

Amman, C. M., Joos, F., Schimel, D. S., Otto-Bliesner, B. L., and Tomas, R.: Solar influence on climate during the past millemnium: results from transient simulations with the NCAR climate system model, Proc. Natl. Acad. Sci. USA, 104, 3713-3718, doi:10.1073/pnas.0605064103, 2007.

Anderson, T. L., Wu, Y., Chu, D. A., Schmid, B., Redemann, J., and Dubovik, O.: Testing the MODIS satellite retrieval of aerosol fine-mode fraction, J. Geophys. Res., 110, D18204, doi:10.1029/2005JD005978, 2005.

Antoine, D. and Morel, A.: A multiple scattering algorithm for atmospheric correction of remotely sensed ocean colour (MERIS instrument): Principle and implementation for atmospheres carrying various aerosols including absorbing ones, Int. J. Remote Sens., 20, 1875-1916, doi:10.1080/014311699212533, 1999.

Antoine, D. and Nobileau, D.: Recent increase of Saharan dust transport over the Mediterranean Sea, as revealed from ocean color satellite (SeaWiFS) observations, J. Geophys. Res., 111, D12214, doi:10.1029/2005JD006795, 2006.

Artale, V., Calmanti, S., Carillo, A., Dell'Aquila, A., Herrmann, M., Pisacane, G., Ruti, P. M., Sannino, G., Struglia, M. V., Giorgi, F., Bi, X., Pal, J. S., and Rauscher, S.: An atmosphere-ocean regional climate model for the Mediterranean area: assessment 
of a present climate simulation, Clim. Dynam., 35, 721-740, doi:10.1007/s00382-009-0691-8, 2010.

Barnaba, F. and Gobbi, G. P.: Aerosol seasonal variability over the Mediterranean region and relative impact of maritime, continental and Saharan dust particles over the basin from MODIS data in the year 2001, Atmos. Chem. Phys., 4, 2367-2391, doi:10.5194/acp-4-2367-2004, 2004.

Basart, S., Pérez, C., Cuevas, E., Baldasano, J. M., and Gobbi, G. P.: Aerosol characterization in Northern Africa, Northeastern Atlantic, Mediterranean Basin and Middle East from direct-sun AERONET observations, Atmos. Chem. Phys., 9, 8265-8282, doi:10.5194/acp-9-8265-2009, 2009.

Bellouin, N., Rae, J., Jones, A., Johnson, C., Haywood, J., and Boucher, O.: Aerosol forcing in the Climate Model Intercomparison Project (CMIP5) simulations by HadGEM2-ES and the role of ammonium nitrate, J. Geophys. Res., 116, D20206, doi:10.1029/2011JD016074, 2011.

Benedetti, A., Morcrette, J.-J., Boucher, O., Dethof, A., Engelen, R. J., Fisher, M., Flentje, H., Huneeus, N., Jones, L., Kaiser, J. W., Kinne, S., Mangold, A., Razinger, M., Simmons, A. J., and Suttie, M.: Aerosol analysis and forecast in the European Centre for Medium-Range Weather Forecasts Integrated Forecast System: 2. Data assimilation, J. Geophys. Res., 114, D13205, doi:10.1029/2008JD011115, 2009.

Benedetti, A., Kaiser, J. W., and Morcrette, J.-J.: [global climate] aerosols [in "state of the climate in 2010"], B. Am. Meteorol. Soc., 92, S65-S67, 2011.

Bergamo, A., Tafuro, A. M., Kinne, S., De Tomasi, F., and Perrone, M. R.: Monthly-averaged anthropogenic aerosol direct radiative forcing over the Mediterranean based on AERONET aerosol properties, Atmos. Chem. Phys., 8, 6995-7014, doi:10.5194/acp8-6995-2008, 2008.

Berthier, S., Chazette, P., Couvert, P., Pelon, J., Dulac, F., Thieuleux, F., Moulin, C., and Pain, T.: Desert dust aerosol columnar properties over ocean and continental Africa from Lidar in-Space Technology Experiment (LITE) and Meteosat synergy, J. Geophys. Res., 111, D21202, doi:10.1029/2005JD006999, 2006.

Bréon, F.-M., Vermeulen, A., and Descloitres, J.: An evaluation of satellite aerosol products against sunphotometers measurements, Remote Sens. Environ., 115, 3102-3111, doi:10.1016/j.rse.2011.06.017, 2011.

Carboni, E., Thomas, G. E., Sayer, A. M., Siddans, R., Poulsen, C. A., Grainger, R. G., Ahn, C., Antoine, D., Bevan, S., Braak, R., Brindley, H., DeSouza-Machado, S., Deuzé, J. L., Diner, D., Ducos, F., Grey, W., Hsu, C., Kalashnikova, O. V., Kahn, R., North, P. R. J., Salustro, C., Smith, A., Tanré, D., Torres, O., and Veihelmann, B.: Intercomparison of desert dust optical depth from satellite measurements, Atmos. Meas. Tech., 5, 1973-2002, doi:10.5194/amt-5-1973-2012, 2012.

Chazette, P., David, C., Lefrère, J., Godin, S., Pelon, J., and Mégie, G.: Comparative lidar study of the optical, geometrical, and dynamical properties of stratospheric post-volcanic aerosols, following the eruptions of El Chichon and Mount Pinatubo, J. Geophys. Res., 100, 23195-23207, doi:10.1029/95JD02268, 1995.

Chin, M., Jacob, D. J., Gardner, G. M., Foreman-Fowler, M. S., Spiro, P. A., and Savoie, D. L.: A global three-dimensional model of tropospheric sulfate, J. Geophys. Res., 101, 18667-18690, doi:10.1029/96JD01221, 1996.
Collins, W. J., Bellouin, N., Doutriaux-Boucher, M., Gedney, N., Halloran, P., Hinton, T., Hughes, J., Jones, C. D., Joshi, M., Liddicoat, S., Martin, G., O’Connor, F., Rae, J., Senior, C., Sitch, S., Totterdell, I., Wiltshire, A., and Woodward, S.: Development and evaluation of an Earth-System model - HadGEM2, Geosci. Model Dev., 4, 1051-1075, doi:10.5194/gmd-4-10512011, 2011.

Dee, D. P., Uppala, S. M., Simmons, A. J., Berrisford, P., Poli, P., Kobayashi, S., Andrae, U., Balmaseda, M. A., Balsamo, G., Bauer, P., Bechtold, P., Beljaars, A. C. M., van de Berg, L., Bidlot, J., Bormann, N., Delsol, C., Dragani, R., Fuentes, M., Geer, A. J., Haimbergere, L., Healy, S. B., Hersbach, H., Hólm, E. V., Isaksen, L., Kallberg, P., Köhler, M., Matricardi, M., McNally, A. P., Monge-Sanzf, B. M., Morcrette, J.-J., Park, B.-K., Peubey, C., de Rosnaya, P., Tavolato, C., Thépaut, J.-N., and Vitart, F.: The ERA-Interim reanalysis: configuration and performance of the data assimilation system, Q. J. Roy. Meteor. Soc., 137, 553597, doi:10.1002/qj.828, 2011.

Donner, L. J., Wyman, B. L., Hemler, R. S., Horowitz, L. W., Ming, Y., Zhao, M., Golaz, J.-C., Ginoux, P., Lin, S.-J., Schwarzkopf, M. D., Austin, J., Alaka, G., Cooke, W. F., Delworth, T. L., Freidenreich, S. M., Gordon, C. T., Griffies, S. M., Held, I. M., Hurlin, W. J., Klein, S. A., Knutson, T. R., Langenhors, A. R., Lee, H.-C., Lin, Y., Magi, B., Malyshev, S. L., Milly, P. C., Naik, V., Nath, M. J., Pincus, R., Ramaswamy, J. J. P. V., Seman, C. J., Shevliakova, E., Sirutis, J. J., Stern, W. F., Stouffer, R. J., Wilson, R. J., Winton, M., Wittenberg, A., and Zeng, F.: The dynamical core, physical parameterizations, and basic simulation characteristics of the atmospheric component of the GFDL global coupled model CM3, J. Climate, 24, 3484-3519, doi:10.1175/2011JCLI3955.1, 2011.

Dubovik, O., Holben, B. N., Eck, T. F., Smirnov, A., Kaufman, Y. J., King, M. D., Tanré, D., and Slutsker, I.: Variability of absorption and optical properties of key aerosol types observed in worldwide locations, J. Atmos. Sci., 59, 590-608, 2002.

Dulac, F. and Chazette, P.: Airborne study of a multi-layer aerosol structure in the eastern Mediterranean observed with the airborne polarized lidar ALEX during a STAAARTE campaign (7 June 1997), Atmos. Chem. Phys., 3, 1817-1831, doi:10.5194/acp-31817-2003, 2003.

Déqué, M. and Somot, S.: Extreme precipitation and high resolution with Aladin, Idöjaras Quaterly Journal of the Hungarian Meteorological Service, 112, 179-190, 2008.

Farda, A., Déqué, M., Somot, S., Horanyi, A., Spiridonov, V., and Toth, H.: Model ALADIN as regional climate model for Central and Eastern Europe, Stud. Geophys. Geod., 54, 313-332, doi:10.1007/s11200-010-0017-7, 2010.

Gao, X., Pal, J. S., and Giorgi, F.: Projected changes in mean and extreme precipitation over the Mediterranean region from a high resolution double nested RCM simulation, Geophys. Res. Lett., 33, L03706, doi:10.1029/2005GL024954, 2006.

Gibelin, A.-L. and Déqué, M.: Anthropogenic climate change over the Mediterranean region simulated by a global variable resolution model, Clim. Dynam., 20, 327-339, doi:10.1007/s00382002-0277-1, 2003.

Giorgi, F. and Lionello, P.: Climate change projections for the Mediterranean region, Global Planet. Change, 63, 90-104, doi:10.1016/j.gloplacha.2007.09.005, 2008. 
Giorgi, F., Coppola, E., Solmon, F., Mariotti, L., Sylla, M. B., Bi, X., Elguindi, N., Diro, G. T., Nair, V., Giuliani, G., Cozzini, S., Guettler, I., O’Brien, T. A., Tawfik, A. B., Shalaby, A., Zakey, A. S., Steiner, A. L., Stordal, F., Sloan, L. C., and Brankovic, C.: RegCM4: model description and preliminary tests over multiple CORDEX domains, Clim. Res., 52, 7-29, doi:10.3354/cr01018, 2012.

Gordon, H. R. and Wang, M.: Retrieval of water-leaving radiance and aerosol optical thickness over the oceans with SeaWiFS: a preliminary algorithm, Appl. Optics, 33, 443-452, 1994.

Guieu, C., Dulac, F., Desboeufs, K., Wagener, T., Pulido-Villena, E., Grisoni, J.-M., Louis, F., Ridame, C., Blain, S., Brunet, C., Bon Nguyen, E., Tran, S., Labiadh, M., and Dominici, J.-M.: Large clean mesocosms and simulated dust deposition: a new methodology to investigate responses of marine oligotrophic ecosystems to atmospheric inputs, Biogeosciences, 7, 27652784, doi:10.5194/bg-7-2765-2010, 2010.

Hamonou, E., Chazette, P., Balis, D., Dulac, F., Schneider, X., Galani, E., Ancellet, G., and Papayannis, A.: Characterization of the vertical structure of Saharan dust export to the Mediterranean basin, J. Geophys. Res., 104, 22257-22270, 1999.

Hatzianastassiou, N., Gkikas, A., Mihalopoulos, N., Torres, O., and Katsoulis, B. D.: Natural versus anthropogenic aerosols in the eastern Mediterranean basin derived from multiyear TOMS and MODIS satellite data, J. Geophys. Res., 114, D24202, doi:10.1029/2009JD011982, 2009.

Hauglustaine, D. A., Hourdin, F., Jourdain, L., Filiberti, M.A., Walters, S., Lamarque, J.-F., and Holland, E. A.: Interactive chemistry in the Laboratoire de Météorologie Dynamique general circulation model: Description and background tropospheric chemistry evaluation, J. Geophys. Res., 109, D04314, doi:10.1029/2003JD003957, 2004.

Herman, J. R., Bhartia, P. K., Torres, O., Hsu, C., Seftor, C., and Celarier, E.: Global distribution of UV-absorbing aerosols from Nimbus 7/TOMS data, J. Geophys. Res., 102, 16911-16922, 1997.

Herman, J. R., Celarier, E., and Larko, D.: UV 380 nm reflectivity of the Earth's surface, clouds and aerosols, J. Geophys. Res., 106, 5335-5351, 2001.

Herman, M., Deuzé, J.-L., Marchand, A., Roger, B., and Lallart, P.: Aerosol remote sensing from POLDER//ADEOS over the ocean: Improved retrieval using a nonspherical particle model, J. Geophys. Res., 110, D10S02, doi:10.1029/2004JD004798, 2005.

Herrmann, M., Somot, S., Calmanti, S., Dubois, C., and Sevault, F.: Representation of spatial and temporal variability of daily wind speed and of intense wind events over the Mediterranean Sea using dynamical downscaling: impact of the regional climate model configuration, Nat. Hazards Earth Syst. Sci., 11, 19832001, doi:10.5194/nhess-11-1983-2011, 2011.

Hohenegger, C. and Vidale, P. L.: Sensitivity of the European climate to aerosol forcing as simulated with a regional climate model, J. Geophys. Res., 110, D06201, doi:10.1029/2004JD005335, 2005.

Holben, B. N., Eck, T. F., Slutsker, I., Tanré, D., Buis, J. P., Setzer, A., Vermote, E., Reagan, J. A., Kaufman, Y., Nakajima, T., Lavenu, F., Jankowiak, I., and Smirnov, A.: AERONET-A Federated Instrument Network and Data Archive for Aerosol Characterization, Remote Sens. Environ., 66, 1-16, doi:10.1016/S00344257(98)00031-5, 1998.
Holben, B. N., Tanré, D., Smirnov, A., Eck, T. F., Slutsker, I., Abuhassan, N., Newcomb, W. W., Schafer, J. S., Chatenet, B., Lavenu, F., Kaufman, Y. J., Castle, J. V., Setzer, A., Markham, B., Clark, D., Frouin, R., Halthore, R., Karneli, A., O’Neill, N. T., Pietras, C., Pinker, R. T., Voss, K., and Zibordi, G.: An emerging ground-based aerosol climatology: Aerosol optical depth from AERONET, J. Geophys. Res., 106, 12067-12097, doi:10.1029/2001JD900014, 2001.

Hourdin, F., Musat, I., Bony, S., Braconnot, P., Codron, F., Dufresne, J.-L., Fairhead, L., Filiberti, M.-A., Friedlingstein, P., Grandpeix, J.-Y., Krinner, G., LeVan, P., Li, Z.-X., and Lott, F.: The LMDZ4 general circulation model: climate performance and sensitivity to parametrized physics with emphasis on tropical convection, Clim. Dynam., 27, 787-813, doi:10.1007/s00382006-0158-0, 2006.

Hovis, W. A., Clark, D. K., Anderson, F., Austin, R. W., Wilson, W. H., Baker, E. T., Ball, D., Gordon, H. R., Mueller, J. L., El-Sayed, S. Z., Sturm, B., Wrigley, R. C., and Yentsch, C. S.: Nimbus-7 Coastal Zone Color Scanner: System description and initial imagery, Science, 210, 60-63, 1980.

Hsu, N. C., Tsay, S.-C., King, M., and Herman, J. R.: Aerosol properties over bright-reflecting source regions, IEEE T. Geosci. Remote, 42, 557-569, doi:10.1109/TGRS.2004.824067, 2004.

Hsu, N. C., Gautam, R., Sayer, A. M., Bettenhausen, C., Li, C., Jeong, M. J., Tsay, S.-C., and Holben, B. N.: Global and regional trends of aerosol optical depth over land and ocean using SeaWiFS measurements from 1997 to 2010, Atmos. Chem. Phys., 12, 8037-8053, doi:10.5194/acp-12-8037-2012, 2012.

Iorio, T. D., di Sarra, A., Sferlazzo, D. M., Cacciani, M., Meloni, D., Monteleone, F., Fua, D., and Fiocco, G.: Seasonal evolution of the tropospheric aerosol vertical profile in the central mediterranean and role of desert dust, J. Geophys. Res., 114, D02201, doi:10.1029/2008JD010593, 2009.

Jacob, D.: A note to the simulation of the annual and interannual variability of the water budget over the Baltic Sea drainage basin, Meteorol. Atmos. Phys., 77, 61-73, 2001.

Jamet, C., Moulin, C., and Thiria, S.: Monitoring aerosol optical properties over the Mediterranean from SeaWiFS images using a neural network inversion, Geophys. Res. Lett., 31, L13107, doi:10.1029/2004GL019951, 2004.

Kahn, R. A., Gaitley, B. J., Martonchik, J. V., Diner, D. J., Crean, K. A., and Holben, B.: Multiangle imaging spectroradiometer (misr) global aerosol optical depth validation based on 2 years of coincident aerosol robotic network (aeronet) observations, J. Geophys. Res., 110, D10S04, doi:10.1029/2004JD004706, 2005.

Kahn, R. A., Gaitley, B. J., Garay, M. J., Diner, D. J., Eck, T. F., Smirnov, A., and Holben, B. N.: Multiangle Imaging SpectroRadiometer global aerosol product assessment by comparison with the Aerosol Robotic Network, J. Geophys. Res., 115, D23209, doi:10.1029/2010JD014601, 2010.

Kaiser, J. W., Benedetti, A., and Morcrette, J.-J.: [global climate] aerosols [in "state of the climate in 2009"], B. Am. Meteorol. Soc., 91, S45-S47, 2010.

Kalivitis, N., Gerasopoulos, E., Vrekoussis, M., Kouvarakis, G., Kubilay, N., Hatzianastassiou, N., Vardavas, I., and Mihalopoulos, N.: Dust transport over the eastern Mediterranean derived from Total Ozone Mapping Spectrometer, Aerosol Robotic Network, and surface measurements, J. Geophys. Res., 112, D03202, doi:10.1029/2006JD007510, 2007. 
Kinne, S., Schulz, M., Textor, C., Guibert, S., Balkanski, Y., Bauer, S. E., Berntsen, T., Berglen, T. F., Boucher, O., Chin, M., Collins, W., Dentener, F., Diehl, T., Easter, R., Feichter, J., Fillmore, D., Ghan, S., Ginoux, P., Gong, S., Grini, A., Hendricks, J., Herzog, M., Horowitz, L., Isaksen, I., Iversen, T., Kirkevåg, A., Kloster, S., Koch, D., Kristjansson, J. E., Krol, M., Lauer, A., Lamarque, J. F., Lesins, G., Liu, X., Lohmann, U., Montanaro, V., Myhre, G., Penner, J., Pitari, G., Reddy, S., Seland, O., Stier, P., Takemura, T., and Tie, X.: An AeroCom initial assessment - optical properties in aerosol component modules of global models, Atmos. Chem. Phys., 6, 1815-1834, doi:10.5194/acp-6-1815-2006, 2006.

Krekov, G. M.: Models of atmospheric aerosols, in: Aerosol Effects on Climate, Univ. of Ariz. Press, Tucson, edited by: Jennings, S. G., 1993.

Lamarque, J.-F., Bond, T. C., Eyring, V., Granier, C., Heil, A., Klimont, Z., Lee, D., Liousse, C., Mieville, A., Owen, B., Schultz, M. G., Shindell, D., Smith, S. J., Stehfest, E., Van Aardenne, J., Cooper, O. R., Kainuma, M., Mahowald, N., McConnell, J. R., Naik, V., Riahi, K., and van Vuuren, D. P.: Historical (1850-2000) gridded anthropogenic and biomass burning emissions of reactive gases and aerosols: methodology and application, Atmos. Chem. Phys., 10, 7017-7039, doi:10.5194/acp10-7017-2010, 2010.

Lamarque, J.-F., Emmons, L. K., Hess, P. G., Kinnison, D. E., Tilmes, S., Vitt, F., Heald, C. L., Holland, E. A., Lauritzen, P. H., Neu, J., Orlando, J. J., Rasch, P. J., and Tyndall, G. K.: CAM-chem: description and evaluation of interactive atmospheric chemistry in the Community Earth System Model, Geosci. Model Dev., 5, 369-411, doi:10.5194/gmd-5-369-2012, 2012.

Lamarque, J.-F., Shindell, D. T., Josse, B., Young, P. J., Cionni, I., Eyring, V., Bergmann, D., Cameron-Smith, P., Collins, W. J., Doherty, R., Dalsoren, S., Faluvegi, G., Folberth, G., Ghan, S. J., Horowitz, L. W., Lee, Y. H., MacKenzie, I. A., Nagashima, T., Naik, V., Plummer, D., Righi, M., Rumbold, S. T., Schulz, M., Skeie, R. B., Stevenson, D. S., Strode, S., Sudo, K., Szopa, S., Voulgarakis, A., and Zeng, G.: The Atmospheric Chemistry and Climate Model Intercomparison Project (ACCMIP): overview and description of models, simulations and climate diagnostics, Geosci. Model Dev., 6, 179-206, doi:10.5194/gmd-6-179-2013, 2013.

Laurent, B., Marticorena, B., Bergametti, G., Léon, J. F., and Mahowald, N. M.: Modeling mineral dust emission from the Sahara desert using new surface properties and soil database, J. Geophys. Res., 113, D14218, doi:10.1029/2007JD009484, 2008.

Lee, Y. H. and Adams, P. J.: Evaluation of aerosol distributions in the GISS-TOMAS global aerosol microphysics model with remote sensing observations, Atmos. Chem. Phys., 10, 2129-2144, doi:10.5194/acp-10-2129-2010, 2010.

Lelieveld, J., Berresheim, H., Borrmann, S., Crutzen, P. J., Dentener, F. J., Fischer, H., Feichter, J., Flatau, P. J., Heland, J., Holzinger, R., Korrmann, R., Lawrence, M. G., Levin, Z., Markowicz, K. M., Mihalopoulos, N., Minikin, A., Ramanathan, V., de Reus, M., Roelofs, G. J., Scheeren, H. A., Sciare, J., Schlager, H., Schultz, M., Siegmund, P., Steil, B., Stephanou, E. G., Stier, P., Traub, M., Warneke, C., Williams, J., and Ziereis, H.: Global Air Pollution Crossroads over the Mediterranean, Science, 298, 794-799, doi:10.1126/science.1075457, 2002.
Levy, R. C., Remer, L. A., Mattoo, S., Vermote, E. F., and Kaufman, Y. J.: Second-generation operational algorithm: Retrieval of aerosol properties over land from inversion of Moderate Resolution Imaging Spectroradiometer spectral reflectance, J. Geophys. Res., 112, D13211, doi:10.1029/2006JD007811, 2007.

Levy, R. C., Remer, L. A., Kleidman, R. G., Mattoo, S., Ichoku, C., Kahn, R., and Eck, T. F.: Global evaluation of the Collection 5 MODIS dark-target aerosol products over land, Atmos. Chem. Phys., 10, 10399-10420, doi:10.5194/acp-10-10399-2010, 2010.

Liousse, C., Penner, J. E., Chuang, C., Walton, J. J., Eddleman, H., and Cachier, H.: A global three-dimensional model study of carbonaceous aerosols, J. Geophys. Res., 101, 19411-19432, doi:10.1029/95JD03426, 1996.

Liu, X., Easter, R. C., Ghan, S. J., Zaveri, R., Rasch, P., Shi, X., Lamarque, J.-F., Gettelman, A., Morrison, H., Vitt, F., Conley, A., Park, S., Neale, R., Hannay, C., Ekman, A. M. L., Hess, P., Mahowald, N., Collins, W., Iacono, M. J., Bretherton, C. S., Flanner, M. G., and Mitchell, D.: Toward a minimal representation of aerosols in climate models: description and evaluation in the Community Atmosphere Model CAM5, Geosci. Model Dev., 5, 709-739, doi:10.5194/gmd-5-709-2012, 2012.

Mallet, M., Roger, J. C., Despiau, S., Dubovik, O., and Putaud, J. P.: Microphysical and optical properties of aerosol particles in urban zone during ESCOMPTE, Atmos. Res., 69, 73-97, doi:10.1016/j.atmosres.2003.07.001, 2003.

Mallet, M., Dubovik, O., Nabat, P., Dulac, F., Kahn, R., Sciare, J., Paronis, D., and Léon, J. F.: Absorption properties of Mediterranean aerosols obtained from multi-year ground-based and satellite remote sensing observations, Atmos. Chem. Phys. Discuss., 13, 9267-9317, doi:10.5194/acpd-13-9267-2013, 2013.

Mangold, A., Backer, H. D., Paepe, B. D., Dewitte, S., Chiapello, I., Derimian, Y., Kacenelenbogen, M., Léon, J.-F., Huneeus, N., Schulz, M., Ceburnis, D., O’Dowd, C., Flentje, H., Kinne, S., Benedetti, A., Morcrette, J.-J., and Boucher, O.: Aerosol analysis and forecast in the European Centre for Medium-Range Weather Forecasts Integrated Forecast System: 3. Evaluation by means of case studies, J. Geophys. Res., 116, D03302, doi:10.1029/2010JD014864, 2011.

Mona, L., Amodeo, A., Pandolfi, M., and Pappalardo, G.: Saharan dust intrusions in the Mediterranean area: Three years of Raman lidar measurements, J. Geophys. Res., 111, D16203, doi:10.1029/2005JD006569, 2006.

Morcrette, J.-J., Boucher, O., Jones, L., Salmond, D., Bechtold, P., Beljaars, A., Benedetti, A., Bonet, A., Kaiser, J. W., Razinger, M., Schulz, M., Serrar, S., Simmons, J., Sofiev, M., Suttie, M., Tompkins, A. M., and Untch, A.: Aerosol analysis and forecast in the european centre for medium-range weather forecasts integrated forecast system: Forward modelling, J. Geophys. Res., 114, D06206, doi:10.1029/2008JD011235, 2009.

Morcrette, J.-J., Benedetti, A., Jones, L., Kaiser, J., Razinger, M., and Suttie, M.: Prognostic Aerosols in the ECMWF IFS: MACC vs. GEMS Aerosols, Tech. Rep. 659, European Centre for Medium-Range Weather Forecasts, available at: http://www. ecmwf.int/publications/library/do/references/list/14, 2011.

Moulin, C., Lambert, C. E., Poitou, J., and Dulac, F.: Long term (1983-1994) calibration of the Meteosat solar (VIS) channel using desert and ocean targets, Int. J. Remote Sens., 17, 1183-1200, 1996. 
Moulin, C., Guillard, F., Dulac, F., and Lambert, C. E.: Longterm daily monitoring of Saharan dust load over ocean using Meteosat ISCCP-B2 data 1. Methodology and preliminary results for 1983-1994 in the Mediterranean, J. Geophys. Res., 102, 16947-16958, 1997a.

Moulin, C., Lambert, C. E., Dulac, F., and Dayan, U.: Control of atmospheric export of dust from North Africa by the North Atlantic Oscillation, Nature, 387, 691-694, 1997b.

Moulin, C., Lambert, C. E., Dayan, U., Masson, V., Ramonet, M., Bousquet, P., Legrand, M., Balkanski, Y. J., Guelle, W., Marticorena, B., Bergametti, G., and Dulac, F.: Satellite climatology of African dust transport in the Mediterranean atmosphere, J. Geophys. Res., 103, 13137-13144, doi:10.1029/98JD00171, 1998.

Moulin, C., Gordon, H. R., Banzon, V. F., and Evans, R. H.: Assessment of Saharan dust absorption in the visible from SeaWiFS imagery, J. Geophys. Res., 106, 18239-18249, 2001.

Myhre, G., Stordal, F., Johnsrud, M., Diner, D. J., Geogdzhayev, I. V., Haywood, J. M., Holben, B. N., Holzer-Popp, T., Ignatov, A., Kahn, R. A., Kaufman, Y. J., Loeb, N., Martonchik, J. V., Mishchenko, M. I., Nalli, N. R., Remer, L. A., SchroedterHomscheidt, M., Tanré, D., Torres, O., and Wang, M.: Intercomparison of satellite retrieved aerosol optical depth over ocean during the period September 1997 to December 2000, Atmos. Chem. Phys., 5, 1697-1719, doi:10.5194/acp-5-1697-2005, 2005.

Nabat, P., Solmon, F., Mallet, M., Kok, J. F., and Somot, S.: Dust emission size distribution impact on aerosol budget and radiative forcing over the Mediterranean region: a regional climate model approach, Atmos. Chem. Phys., 12, 10545-10567, doi:10.5194/acp-12-10545-2012, 2012.

Omar, A. H., Winker, D. M., Vaughan, M. A., Hu, Y., Trepte, C. R., Ferrare, R. A., Lee, K.-P., and Hostetler, C. A.: The CALIPSO Automated Aerosol Classification and Lidar Ratio Selection Algorithm, J. Atmos. Ocean. Technol., 26, 1994-2014, doi:10.1175/2009JTECHA1231.1, 2009.

Papadimas, C. D., Hatzianastassiou, N., Mihalopoulos, N., Querol, X., and Vardavas, I.: Spatial and temporal variability in aerosol properties over the Mediterranean basin based on 6year (2000-2006) MODIS data, J. Geophys. Res., 113, D11205, doi:10.1029/2007JD009189, 2008.

Papadimas, C. D., Hatzianastassiou, N., Mihalopoulos, N., Kanakidou, M., Katsoulis, B. D., and Vardavas, I.: Assessment of the MODIS Collections C005 and C004 aerosol optical depth products over the Mediterranean basin, Atmos. Chem. Phys., 9, 29872999, doi:10.5194/acp-9-2987-2009, 2009.

Pinker, R. T., Zhang, B., and Dutton, E. G.: Do satellites detect trends in surface solar radiation?, Science, 308, 850-854, doi:10.1126/science.1103159, 2005.

Qian, Y., Giorgi, F., Huang, Y., Chameides, W., and Luo, C.: Regional simulation of anthropogenic sulfur over East Asia and its sensitivity to model parameters, Tellus, 53B, 171-191, doi:10.1034/j.1600-0889.2001.d01-14.x, 2001.

Randles, C. A., Kinne, S., Myhre, G., Schulz, M., Stier, P., Fischer, J., Doppler, L., Highwood, E., Ryder, C., Harris, B., Huttunen, J., Ma, Y., Pinker, R. T., Mayer, B., Neubauer, D., Hitzenberger, R., Oreopoulos, L., Lee, D., Pitari, G., Di Genova, G., Quaas, J., Rose, F. G., Kato, S., Rumbold, S. T., Vardavas, I., Hatzianastassiou, N., Matsoukas, C., Yu, H., Zhang, F., Zhang, H., and $\mathrm{Lu}, \mathrm{P}$.: Intercomparison of shortwave radiative transfer schemes in global aerosol modelling: results from the AeroCom Radia- tive Transfer Experiment, Atmos. Chem. Phys., 13, 2347-2379, doi:10.5194/acp-13-2347-2013, 2013.

Remer, L. A., Kaufman, Y. J., Tanré, D., Mattoo, S., Chu, D. A., Martins, J. V., Li, R.-R., Ichoku, C., Levy, R. C., Kleidman, R. G., Eck, T. F., Vermote, E., and Holben, B. N.: The MODIS Aerosol Algorithm, Products, and Validation, J. Atmos. Sci., 62, 947-973, doi:10.1175/JAS3385.1, 2005.

Robock, A.: Volcanic eruptions and climate, Rev. Geophys., 38, 191-219, doi:10.1029/1998RG000054, 2000.

Rodá, F., Bellot, J., Avila, A., Escarré, A., Pinol, J., and Terradas, J.: Saharan dust and the atmospheric inputs of elements and alkalinity to mediterranean ecosystems, Water, Air Soil Pollut., 66, 277-288, doi:10.1007/BF00479851, 1993.

Rosenfeld, D., Rudich, Y., and Lahav, R.: Desert dust suppressing precipitation: A possible desertification feedback loop, Proc. Natl. Acad. Sci. USA, 98, 5975-5980, doi:10.1073/pnas.101122798, 2001.

Ruckstuhl, C., Philipona, R., Behrens, K., Coen, M. C., Dürr, B., Heimo, A., Mätzler, C., Nyeki, S., Ohmura, A., Vuilleumier, L., Weller, M., Wehrli, C., and Zelenka, A.: Aerosol and cloud effects on solar brightening and the recent rapid warming, Geophys. Res. Lett., 35, L12708, doi:10.1029/2008GL034228, 2008.

Sanchez, E., Gallardo, C., Gaertner, M. A., Arribas, A., and Castro, M.: Future climate extreme events in the Mediterranean simulated by a regional climate model: a first approach, Global Planet. Change, 44, 163-180, 2004.

Santer, R., Carrere, V., Dubuisson, P., and Roger, J. C.: Atmospheric correction over land for MERIS, Int. J. Remote Sens., 20, 18191840, doi:10.1080/014311699212506, 1999.

Sayer, A. M., Hsu, N. C., Bettenhausen, C., Ahmad, Z., Holben, B. N., Smirnov, A., Thomas, G. E., and Zhang, J.: SeaWiFS Ocean Aerosol Retrieval (SOAR): Algorithm, validation, and comparison with other datasets, J. Geophys. Res., 117, D01173206, doi:10.1029/2011JD016599, 2012.

Sciare, J., Oikonomou, K., Favez, O., Liakakou, E., Markaki, Z., Cachier, H., and Mihalopoulos, N.: Long-term measurements of carbonaceous aerosols in the Eastern Mediterranean: evidence of long-range transport of biomass burning, Atmos. Chem. Phys., 8, 5551-5563, doi:10.5194/acp-8-5551-2008, 2008.

Shindell, D. T., Lamarque, J.-F., Schulz, M., Flanner, M., Jiao, C., Chin, M., Young, P. J., Lee, Y. H., Rotstayn, L., Mahowald, N., Milly, G., Faluvegi, G., Balkanski, Y., Collins, W. J., Conley, A. J., Dalsoren, S., Easter, R., Ghan, S., Horowitz, L., Liu, X., Myhre, G., Nagashima, T., Naik, V., Rumbold, S. T., Skeie, R., Sudo, K., Szopa, S., Takemura, T., Voulgarakis, A., Yoon, J.-H., and Lo, F.: Radiative forcing in the ACCMIP historical and future climate simulations, Atmos. Chem. Phys., 13, 2939-2974, doi:10.5194/acp-13-2939-2013, 2013a.

Shindell, D. T., Pechony, O., Voulgarakis, A., Faluvegi, G., Nazarenko, L., Lamarque, J.-F., Bowman, K., Milly, G., Kovari, B., Ruedy, R., and Schmidt, G. A.: Interactive ozone and methane chemistry in GISS-E2 historical and future climate simulations, Atmos. Chem. Phys., 13, 2653-2689, doi:10.5194/acp-13-26532013, 2013b.

Skeie, R. B., Berntsen, T. K., Myhre, G., Tanaka, K., Kvalevåg, M. M., and Hoyle, C. R.: Anthropogenic radiative forcing time series from pre-industrial times until 2010, Atmos. Chem. Phys., 11, 11827-11857, doi:10.5194/acp-11-11827-2011, 2011. 
Solmon, F., Giorgi, F., and Liousse, C.: Aerosol modelling for regional climate studies: application to anthropogenic particles and evaluation over a European/African domain, Tellus B., 58, 5172, doi:10.1111/j.1600-0889.2005.00155.x, 2006.

Solmon, F., Mallet, M., Elguindi, N., Giorgi, F., Zakey, A., and Konaré, A.: Dust aerosol impact on regional precipitation over western Africa, mechanisms and sensitivity to absorption properties, Geophys. Res. Lett., 35, L24705, doi:10.1029/2008GL035900, 2008.

Somot, S., Sevault, F., Déqué, M., and Crépon, M.: 21st century climate change scenario for the Mediterranean using a coupled atmosphere-ocean regional climate model, Global Planet. Change, 63, 112-126, doi:10.1016/j.gloplacha.2007.10.003, 2008.

Stowe, L. L., Ignato, A. M., and Singh, R. R.: Development, validation, and potential enhancements to the second-generation operational aerosol product at the National Environmental Satellite, Data, and Information Service of the National Oceanic and Atmospheric Administration, J. Geophys. Res., 102, 16923-16934, 1997.

Szopa, S., Balkanski, Y., Schulz, M., Bekki, S., Cugnet, D., Fortems-Cheiney, A., Turquety, S., Cozic, A., Déandreis, C., Hauglustaine, D., Idelkadi, A., Lathière, J., Lefevre, F., Marchand, M., Vuolo, R., Yan, N., and Dufresne, J.-L.: Aerosol and ozone changes as forcing for climate evolution between 1850 and 2100, Climate dynamics, 40, 2223-2250, doi:10.1007/s00382012-1408-y, 2013.

Tanré, D., Geleyn, J.-F., and Slingo, J. M.: First results of the introduction of an advanced aerosol-radiation interaction in the ECMWF low resolution global model, in: Aerosols and Their Climate Effects, edited by: Gerber, H. E. and Deepak, A., A. Deepak, 133-147, 1984.

Tanré, D., Kaufman, Y. J., Herman, M., and Mattoo, S.: Remote sensing of aerosol properties over oceans using the MODIS/EOS spectral radiances, J. Geophys. Res., 102, 16971-16988, 1997.

Tanré, D., Bréon, F. M., Deuzé, J. L., Herman, M., Goloub, P., Nadal, F., and Marchand, A.: Global observation of anthropogenic aerosols from satellite, Geophys. Res. Lett., 28, 45554558, doi:10.1029/2001GL013036, 2001.

Tanré, D., Bréon, F. M., Deuzé, J. L., Dubovik, O., Ducos, F., François, P., Goloub, P., Herman, M., Lifermann, A., and Waquet, F.: Remote sensing of aerosols by using polarized, directional and spectral measurements within the A-Train: the PARASOL mission, Atmos. Meas. Tech., 4, 1383-1395, doi:10.5194/amt-4-1383-2011, 2011.

Taylor, K. E.: Summarizing multiple aspects of model performance in a single diagram, J. Geophys. Res., 106, 7183-7192, doi:10.1029/2000JD900719, 2001.

Tegen, I. and Fung, I.: Contribution to the atmospheric mineral aerosol load from land surface modification, J. Geophys. Res., 100, 18707-18726, doi:10.1029/95JD02051, 1995.

Tegen, I., Hollrig, P., Chin, M., Fung, I., Jacob, D., and Penner, J.: Contribution of different aerosol species to the global aerosol extinction optical thickness: Estimates from model results, J. Geophys. Res., 102, 23895-23915, 1997.

Textor, C., Schulz, M., Guibert, S., Kinne, S., Balkanski, Y., Bauer, S., Berntsen, T., Berglen, T., Boucher, O., Chin, M., Dentener, F., Diehl, T., Easter, R., Feichter, H., Fillmore, D., Ghan, S., Ginoux, P., Gong, S., Grini, A., Hendricks, J., Horowitz, L., Huang, P., Isaksen, I., Iversen, I., Kloster, S., Koch, D., Kirkevåg, A., Krist- jansson, J. E., Krol, M., Lauer, A., Lamarque, J. F., Liu, X., Montanaro, V., Myhre, G., Penner, J., Pitari, G., Reddy, S., Seland, Ø., Stier, P., Takemura, T., and Tie, X.: Analysis and quantification of the diversities of aerosol life cycles within AeroCom, Atmos. Chem. Phys., 6, 1777-1813, doi:10.5194/acp-6-1777-2006, 2006.

Thieuleux, F., Moulin, C., Bréon, F. M., Maignan, F., Poitou, J., and Tanré, D.: Remote sensing of aerosols over the oceans using MSG/SEVIRI imagery, Ann. Geophys., 23, 3561-3568, doi:10.5194/angeo-23-3561-2005, 2005.

Thomson, A. M., Calvin, K. V., Smith, S. J., Kyle, G. P., Volke, A., Patel, P., Delgado-Arias, S., Bond-Lamberty, B., Wise, M. A., Clarke, L. E., and Edmonds, J. A.: RCP4.5: a pathway for stabilization of radiative forcing by 2100 , Clim. Change, 109, 77-94, doi:10.1007/s10584-011-0151-4, 2011.

Tompkins, A. M., Cardinali, C., Morcrette, J.-J., and Rodwell, M.: Influence of aerosol climatology on forecasts of the African Easterly Jet, Geophys. Res. Lett., 32, L10801, doi:10.1029/2004GL022189, 2005.

Torres, O., Bhartia, P., Herman, J., Sinyuk, A., and Holben, B.: A Long-Term Record of Aerosol Optical Depth from TOMS Observations and Comparison to AERONET Measurements, J. Atmos. Sci., 59, 398-413, 2002.

Vaughan, M., Young, S., Winker, D., Powell, K., Omar, A., Liu, Z., Hu, Y., and Hostetler, C.: Fully automated analysis of space-based lidar data: an overview of the CALIPSO retrieval algorithms and data products, Proc. SPIE, 5575, 16-30, doi:10.1117/12.572024, 2004.

Vautard, R., Yiou, P., and van Oldenborgh, G. J.: Decline of fog, mist and haze in Europe over the past 30 years, Nat. Geosci., 2, 115-119, doi:10.1038/ngeo414, 2009.

Vidot, J., Santer, R., and Aznay, O.: Evaluation of the MERIS aerosol product over land with AERONET, Atmos. Chem. Phys., 8, 7603-7617, doi:10.5194/acp-8-7603-2008, 2008.

Wang, H., Shi, G., Li, S., Li, W., Wang, B., and Huang, Y.: The impacts of optical properties on radiative forcing due to dust aerosol, Adv. Atmos. Sci., 23, 431-441, doi:10.1007/s00376006-0431-5, 2006.

Wang, M., Knobelspiesse, K. D., and McClain, C. R.: Study of the Sea-Viewing Wide Field-of-View Sensor (SeaWiFS) aerosol optical property data over ocean in combination with the ocean color products, J. Geophys. Res., 110, D10S06, doi:10.1029/2004JD004950, 2005.

Watanabe, S., Hajima, T., Sudo, K., Nagashima, T., Takemura, T., Okajima, H., Nozawa, T., Kawase, H., Abe, M., Yokohata, T., Ise, T., Sato, H., Kato, E., Takata, K., Emori, S., and Kawamiya, M.: MIROC-ESM 2010: model description and basic results of CMIP5-20c3m experiments, Geosci. Model Dev., 4, 845-872, doi:10.5194/gmd-4-845-2011, 2011.

Wild, M.: Global dimming and brightening: A review, J. Geophys. Res., 114, D00D16, doi:10.1029/2008JD011470, 2009.

Winker, D., Vaughan, M., Omar, A., Hu, Y., Powell, K., Liu, Z., Hunt, W. H., and Young, S. A.: Overview of the CALIPSO Mission and CALIOP Data Processing Algorithms, J. Atmos. Ocean. Technol., 26, 2310-2323, doi:10.1175/2009JTECHA1281.1, 2009.

Yu, H., Chin, M., Remer, L. A., Kleidman, R. G., Bellouin, N., Bian, H., and Diehl, T.: Variability of marine aerosol finemode fraction and estimates of anthropogenic aerosol component 
over cloud-free oceans from the Moderate Resolution Imaging Spectroradiometer (MODIS), J. Geophys. Res., 114, D10206, doi:10.1029/2008JD010648, 2009.

Zakey, A. S., Solmon, F., and Giorgi, F.: Implementation and testing of a desert dust module in a regional climate model, Atmos. Chem. Phys., 6, 4687-4704, doi:10.5194/acp-6-4687-2006, 2006.

Zakey, A. S., Giorgi, F., and Bi, X.: Modeling of sea salt in a regional climate model: Fluxes and radiative forcing, J. Geophys. Res., 113, D14221, doi:10.1029/2007JD009209, 2008.

Zubler, E. M., Folini, D., Lohmann, U., Lüthi, D., Muhlbauer, A., Pousse-Nottelmann, S., Schär, C., and Wild, M.: Implementation and evaluation of aerosol and cloud microphysics in a regional climate model, J. Geophys. Res., 116, D02211, doi:10.1029/2010JD014572, 2011a.
Zubler, E. M., Folini, D., Lohmann, U., Lüthi, D., Schär, C., and Wild, M.: Simulation of dimming and brightening in europe from 1958 to 2001 using a regional climate model, J. Geophys. Res., 116, D18205, doi:10.1029/2010JD015396, 2011 b.

Zubler, E. M., Lohmann, U., Lüthi, D., and Schär, C.: Intercomparison of aerosol climatologies for use in a regional climate model over Europe, Geophys. Res. Lett., 116, L15705, doi:10.1029/2011GL048081, 2011c. 